EPRA International Journal of Economic and Business Review-Peer Reviewed Journal

Volume - 9, Issue - 5, May 2021 | e-ISSN: 2347 - 9671| p- ISSN: 2349 - 0187

\title{
THE SOCIAL CLASS VARIATION IN HEALTH CARE EXPENDITURE: A CASE STUDY OF KHALLIKOTE BLOCK, GANJAM DISTRICT, ODISHA
}

\author{
Ashok Bhukta ${ }^{1}$, Prof. Sudhakar Patra ${ }^{2}$ \\ 1 Ph.D. Research Scholar, Department of Economics, Berhampur University \\ ${ }^{2}$ Research Supervisor, Department of Economics, Berhampur University
}

\begin{abstract}
DOI No: 10.36713/epra6979

Article DOI URL: https://doi.org/10.36713/epra6979
\end{abstract}

This objective carries the primary data collected through a questionnaire from my study area and analyses of the impact of health care on the socio-economic development and the level of living of the social class families compared to other families. This also focuses on the problems and preferences of the health care expenditure burden of social class families.

This present study was undertaken to investigate the existing health problems and healthcare practice of the social class (SC, ST, and OBC) communities of Khallikote Block in Ganjam District based on the present scenario, which exists between the SC, ST, and OBC groups. The findings of the study indicated that the demographic profile, socioeconomic status, general health status, but still lack of knowledge as well as poor availability of medical institution people intended to use traditional herbal medicine. The housing status of the social class community households needs to be improved through the help of village Panchayat should be oriented by Indira Awas yojana, and help of the people of construct good houses. It is necessary to provide orientation to village Panchayat about healthy housing and sanitation in the tribal communities. The village must be connected with the provision of "Rural Drinking Water" facilities in the social class village area, and villages to have safe drinking water in the villages as well in the community.

The study has the following limitations: The study has depicted the current situation of the Khallikote Block in Odisha; the result may not be relevant to other class of people. The study is limited to a cross-section sample of 348 households of the selected sample villages in Langaleswar and Khojapalli Panchayat. It has been assumed that the respondents are true and honest while filling the questionnaire and there is no bias. Due to time and resource limitations, a full-length survey is not possible with a wider representation of data. Insurgency problem in the state created a problem for data collection from interior parts of the state. Despite these limitations, an attempt has been made to make the study more scientific and reliable by testing the reliability of the primary data.

KEYWORDS: Health care expenditure, Income, cross-section sample, Regression, demographic profile.

\section{INTRODUCTION}

Langaleswar and Khojapalli are the mediumsized villages located in Khallikote Block of Ganjam district, Odisha with absolute 737 and 663 families living. Langaleswar, Khojapalli villages have the Population of 1742 and 1470 respectively of which 902 and 827 are males while 840 and 643 are females according to Population Census 2011. In Langaleswar

(C) 2021 EPRA JEBR ｜EPRA International Journal of Economic and Business Review ｜ www.eprajournals.com म 1 
and Khojapalli villages Population of children with age $0-6$ is 252 and 245 which makes up $14.47 \%$ and $16.67 \%$ of the absolute Population of the villages. The normal Sex Ratio of Langaleswar and Khojapalli villages is 931 and 777 respectively which is lower and lower than Odisha state where the sex ratio 979. Child Sex Ratio for the Langaleswar and Khojapalli according to enumeration is 953 and 947 , higher than Odisha normal of 941. Langaleswar and Khojapalli villages have a higher education rate contrasted with Odisha. In 2011, the proficiency pace of Langaleswar village was $80.47 \%$ and $67.11 \%$ contrasted with $72.87 \%$ of Odisha. In Langaleswar and Khojapalli male proficiency remains at $89.41 \%$ and $90.65 \%$ while the female education rate was $70.81 \%$ and $45.76 \%$. According to the constitution of India and Panchyati Raaj Act, Langaleswar and Khojapalli villages both are administrated by Sarpanch (Head of Village) which is chosen as illustrative of villages. Our site, don't have data about schools and clinic in Langaleswar village. In Langaleswar village, out of the absolute populace, 530 were occupied with work exercises. $56.42 \%$ of labourers portray their work as Main Work (Employment or Earning over 6 Months) while 43.58\% were associated with Marginal action giving occupation to under a half year. Out of 530 experts occupied with main work, 61 were cultivators (proprietor or coproprietor) while 22 were agricultural workers. In Khojapalli town, the greater part of the town populace is from Schedule Tribe (ST). Scheduled Tribe (ST) comprises $97.04 \%$ of the absolute populace in Khojapalli village. There is no populace of Schedule Caste (SC) in Khojapalli village of Ganjam.

This objective provides information about how all the data are accumulated for the study, the sources, the procedures used to choose the sources and samples for the survey, the statistical techniques used to interpret the raw data. It addresses all the facts of drafting, validation and pilot analysis of the questionnaire. Finally, this approach provides a peek into how the data gathered have been processed and used for research purposes.

\section{The Need for the Field Study}

The discussions in objective based on secondary data give an overall picture of the existing set up of health care service and the role of various agencies involved in the implementation of different health care schemes in Odisha. The public sector investments in health care in Odisha have been analyzed in this objective from a macro standpoint. From the discussions in those objective, it is clear that macro-level study based on secondary data can describe the present state of affairs in the primary health care of the state and indicate the relative position compared to primary health care elsewhere in the world. However, the analysis based on aggregated data fails to implement, impact and effectiveness of specific health care schemes on target population groups and the relative importance of government and nongovernment sectors in implementing various schemes of rural health care. However, the available secondary data do not reveal the extent to which the benefit of public expenditure has percolated to the people. To obtain an answer to such questions it is necessary to approach the problem from a micro point of view, i.e., it is necessary to investigate the grass-root level. Primary data have been collected with the help of a semi-structured questionnaire from 348 Khallikote Block households, randomly selected from the four Villages of Khallikote Block where Langaleswar, Telidhiha, Kumarsing, and Badapalli rehabilitation programme had been implemented by the government. Accordingly, a field survey was carried out as a part of the study during the second quarter of 2019 at one selected area of the Ganjam district of Odisha.

\section{Selection of Locations for Field Study}

To become a true representative of the state, the field study should cover a fairly larger number of rural areas of the state. But, due to constraints of time, manpower and other resources of this small survey, it is almost impossible to cover the entire state in the field survey. Thus, the field survey had to be confined to a relatively small area. After preliminary survey, the Ganjam District was selected as the broad location for field study. The district includes Khallikote Block, the only major city in the region. However, the rural areas of the district are not particularly better off than villages in any other parts of the state in terms of socioeconomic development.

\section{Objectives of the field study}

Each research study is conducted with some intentions. The present research study intends to make sure the answers to the questions through the application of technical procedures and methods. While carrying out the study, it is intended to achieve the following objectives. The main objectives of the field study are:

* To examine the social class variation in health care expenditure in Langaleswar and Khojapalli Panchayat, Khallikote Block, Ganjam district, Odisha.

* To identify factors determining rural households per capita expenditure on health care provision.

* To assess the variation in the economic burden of health care expenditure among the social class caste groups.

To provide suggestions to improve the standard of living of the Khallikote Block population based on the study results. 


\section{Hypotheses of the study}

Based on the problem statements, objectives of the study the following Null hypotheses have been framed for empirical verification.

$\mathrm{H}_{01}$ : There is no significant difference exist between the health care expenditure and income of the social class groups.
Demographic and Socio-Economic Profile of the Population Selected for the Research

In any economic survey or research, the role of the demographic profile of the respondents plays a vital role in explaining various economic concepts and theories. Not only the demographic profile but also the socio-economic profile together plays a pivotal role in establishing a relationship between different exogenous and endogenous based on the socio-economic characteristics of the sample. Many demographic and socio-economic variables have been used for collecting the primary data which have been depicted in detail below.

\section{Gender of the Respondents}

Table-1: Gender grouping of the Respondents

\begin{tabular}{|c|c|c|c|c|}
\hline Gender & Frequency & Contribution \% & Valid Percent & Cumulative Percent \\
\hline Female & 204 & 58.62 & 58.62 & 58.62 \\
\hline Male & 144 & 41.38 & 41.38 & 100.00 \\
\hline Total & 348 & 100.00 & 100.00 & \\
\hline
\end{tabular}

Sources: Computed by author

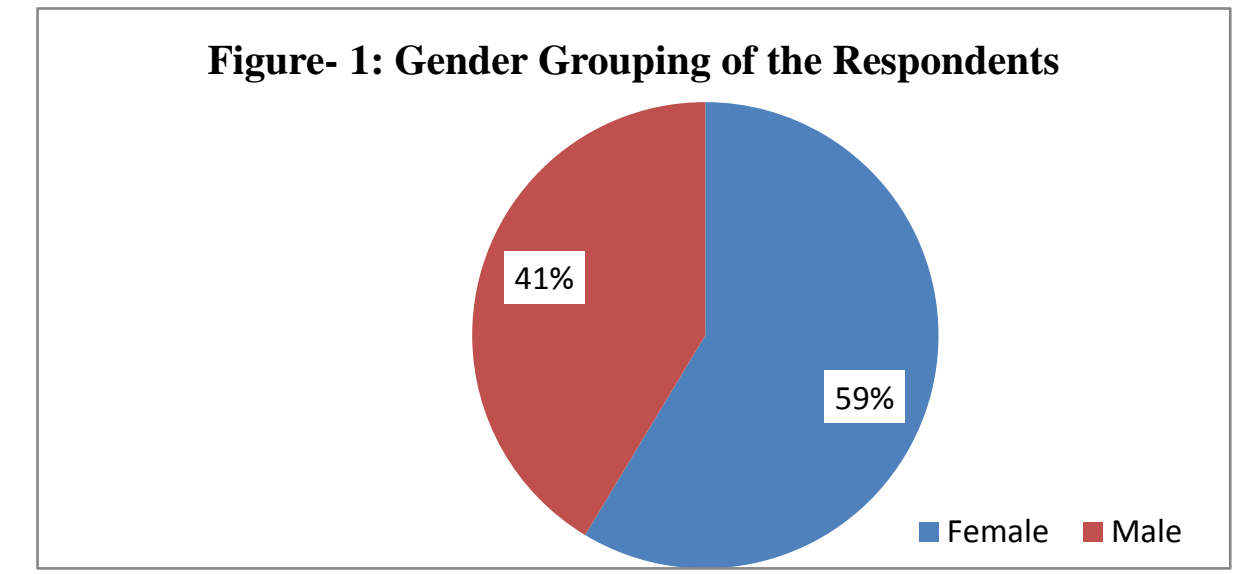

Sources: Computed by author

The above figure shows the gender categorization of the respondents' interview for the survey. In Khallikote Block, the male member is the head of a family, however, an earnest attempt has been made to contact as many as female respondents to create a balance in the number of responses in the survey. Only one member has been chosen from a household for the survey and there are nearly $59 \%$ of female and $41 \%$ male respondents have participated in the survey.

\section{Age Group of the Respondents}

\begin{tabular}{|c|c|c|c|c|}
\hline Age of Households & Frequency & Contribution \% & Valid Percent & $\begin{array}{c}\text { Cumulative } \\
\text { Percent }\end{array}$ \\
\hline $18-30$ & 65 & 18.68 & 18.68 & 18.68 \\
\hline $31-40$ & 107 & 30.75 & 30.75 & 49.43 \\
\hline $41-50$ & 117 & 33.62 & 33.62 & 83.05 \\
\hline More than 50 & 59 & 16.95 & 16.95 & 100.00 \\
\hline Total & 348 & 100.00 & 100.00 & \\
\hline
\end{tabular}

Sources: Computed by author 


\section{Figure-2 : Age of the Respondents}

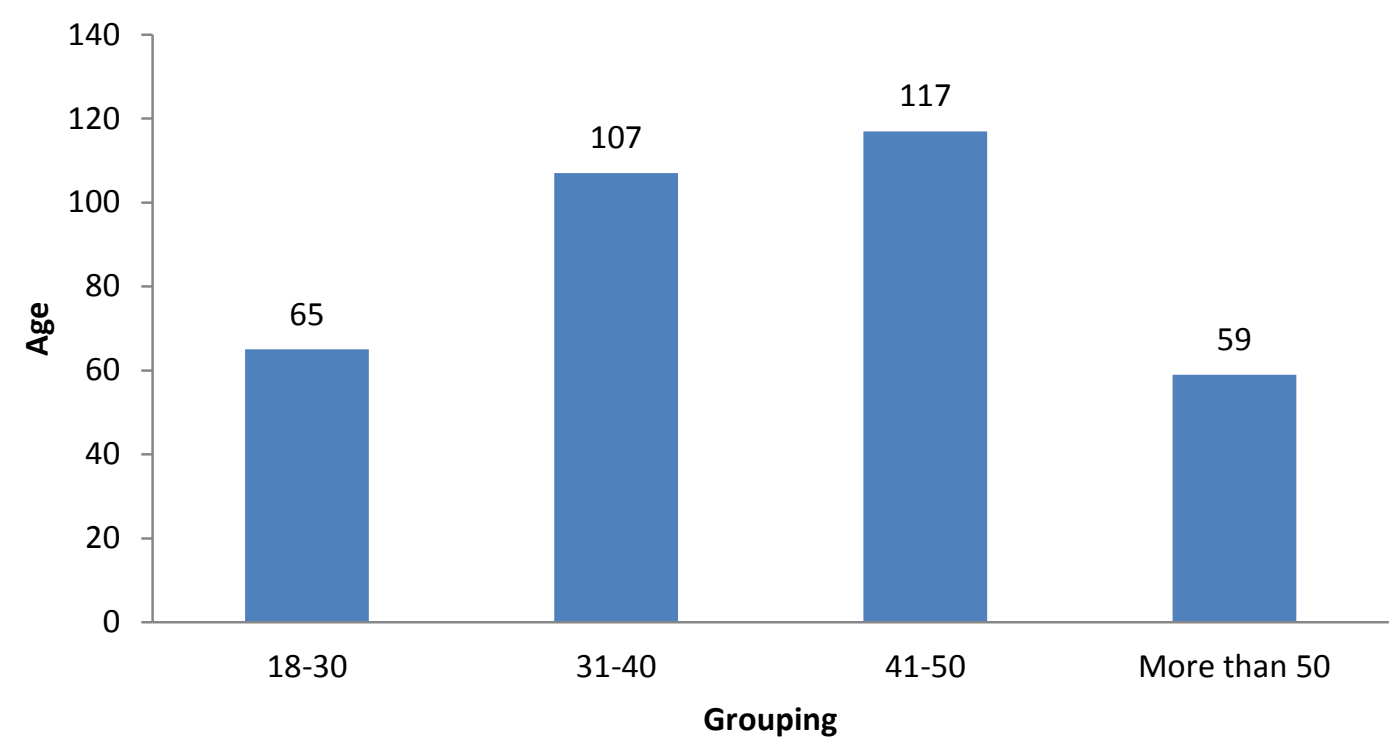

Sources: Computed by author

The above table depicts the classification of the age of the respondents who participated in the survey from the four Villages of Khallikote Block such as; Langaleswar, Telidhiha, Kumarsing and Badapalli in Ganjam District. It can be observed that around 18.68\% of the respondents are young and in the age group of 18 to 30 years. The samples consist of a maximum number of participants i.e. (33.62\%) belonging to the age group of 41 to 50 years. Whereas, there are only $30.75 \%$ of the respondents belong to the age group of below 31-40 years. Further, it can also be observed that the number of participants more than 50 years of age $(16.95 \%)$ are comparatively less than those of the participants of $33.62 \%$ belongs to the age group of $41-50$ years.

\section{Type of Family of the respondents}

Table-3: Family Type of the Respondents

\begin{tabular}{|l|c|c|c|c|c|}
\hline \multicolumn{1}{|c|}{ Villages } & $\begin{array}{c}\text { Nuclear } \\
\text { Family }\end{array}$ & Contribution \% & Joint Family & Contribution \% & $\begin{array}{c}\text { Total } \\
\text { Family }\end{array}$ \\
\hline Langaleswar & 12 & 10.26 & 75 & 32.47 & 87 \\
\hline Telidhiya & 25 & 21.37 & 62 & 26.84 & 87 \\
\hline Badapalli & 30 & 25.64 & 57 & 24.68 & 87 \\
\hline Kumarsing & 50 & 42.74 & 37 & 16.02 & 87 \\
\hline Total & $\mathbf{1 1 7}$ & $\mathbf{1 0 0 . 0 0}$ & $\mathbf{2 3 1}$ & $\mathbf{1 0 0 . 0 0}$ & $\mathbf{3 4 8}$ \\
\hline
\end{tabular}

Sources: Computed by author 


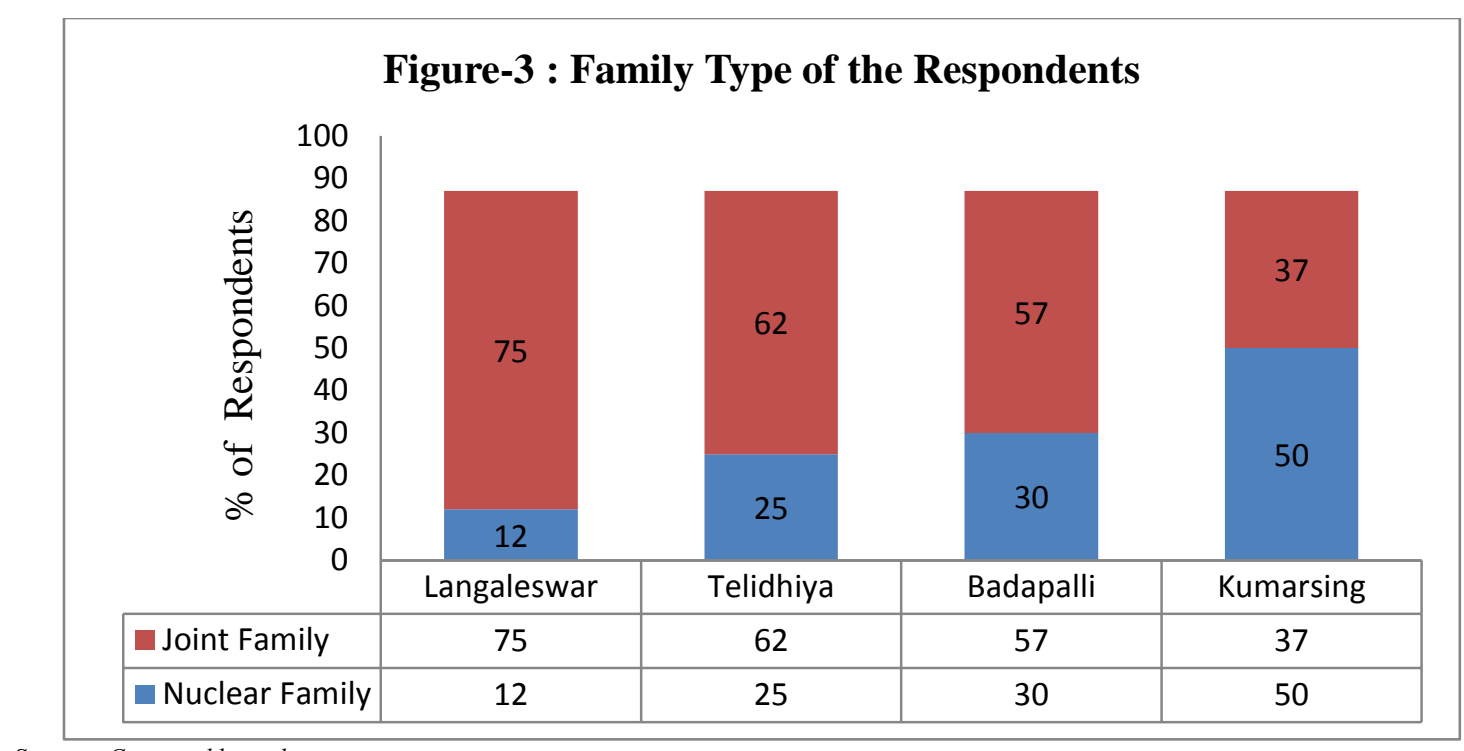

Sources: Computed by author

The table and figures given above show the types of a family the respondents belong to. It can be observed that the number of nuclear families is significantly less than that of the joint families. Similarly, the highest numbers of nuclear families are found in Langaleswar Panchayat of Langaleswar Village compared to the other sample Villages. On the contrary, the number of joint families in Langaleswar Village is higher than the other sample Villages. $32.47 \%$ of the participants are living in joint families where the number of family members is more than $16.02 .42 .74 \%$ of the respondents are living in a nuclear family.

\section{Family size of the respondents}

Table-4: Family Size of the Respondents

\begin{tabular}{|c|c|c|c|c|}
\hline $\begin{array}{c}\text { Number of Family } \\
\text { Members }\end{array}$ & $\begin{array}{c}\text { Family } \\
\text { Members }\end{array}$ & $\begin{array}{c}\text { Contribution } \\
\text { \% }\end{array}$ & Valid Percent & Cumulative \% \\
\hline 3 & 35 & 10.06 & 10.06 & 10.06 \\
\hline 4 & 55 & 15.80 & 15.80 & 25.86 \\
\hline 5 & 62 & 17.82 & 17.82 & 43.68 \\
\hline 6 & 65 & 18.68 & 18.68 & 62.36 \\
\hline 7 & 52 & 14.94 & 14.94 & 77.30 \\
\hline 9 & 41 & 11.78 & 11.78 & 89.08 \\
\hline Total & 38 & 10.92 & 10.92 & 100.00 \\
\hline
\end{tabular}

Sources: Computed by author 


\section{Figure-4: Family Type of the Respondents}

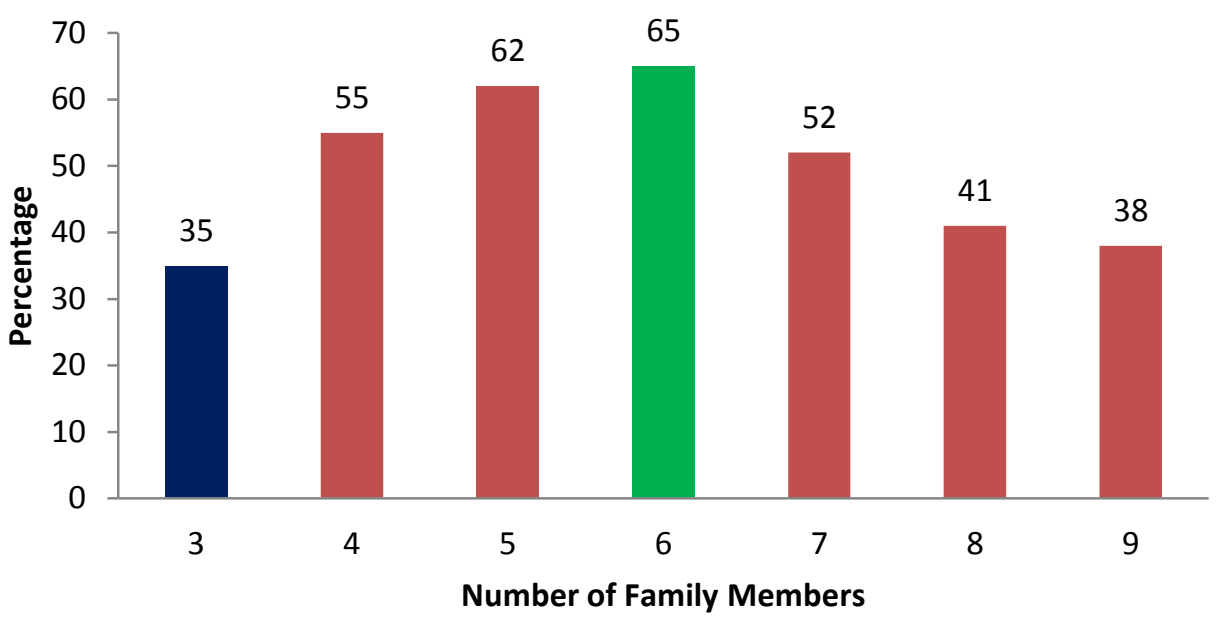

Sources: Computed by author

The table given above depicts the size of the family or the number of family members in the family of the respondents. It can be observed that a larger number of families have 6 number members i.e. $18.68 \%$. On the contrary, the number of respondents having 5 and 8 family members is $17.82 \%$ and $11.78 \%$ respectively. Similarly, respondents having 4 and 8 number members are $15.80 \%$ and $11.78 \%$ respectively. Only $10.06 \%$ of the respondents are having 3 members in their family.

\section{Number of Children in the family of the respondent}

Table-5: Number of Children in the family of the respondent

\begin{tabular}{|c|c|c|c|c|}
\hline Number of Children & Frequency & Contribution \% & Valid Percent & Cumulative Percent \\
\hline No Children & 52 & 14.94 & 14.94 & 14.94 \\
\hline One Child & 56 & 16.09 & 16.09 & 31.03 \\
\hline Two Children & 88 & 25.29 & 25.29 & 56.32 \\
\hline Three Children & 85 & 24.43 & 24.43 & 80.75 \\
\hline More than 3 Children & 67 & 19.25 & 19.25 & 100.00 \\
\hline Total & 348 & 100.00 & 100.00 & \\
\hline
\end{tabular}

Sources: Computed by author

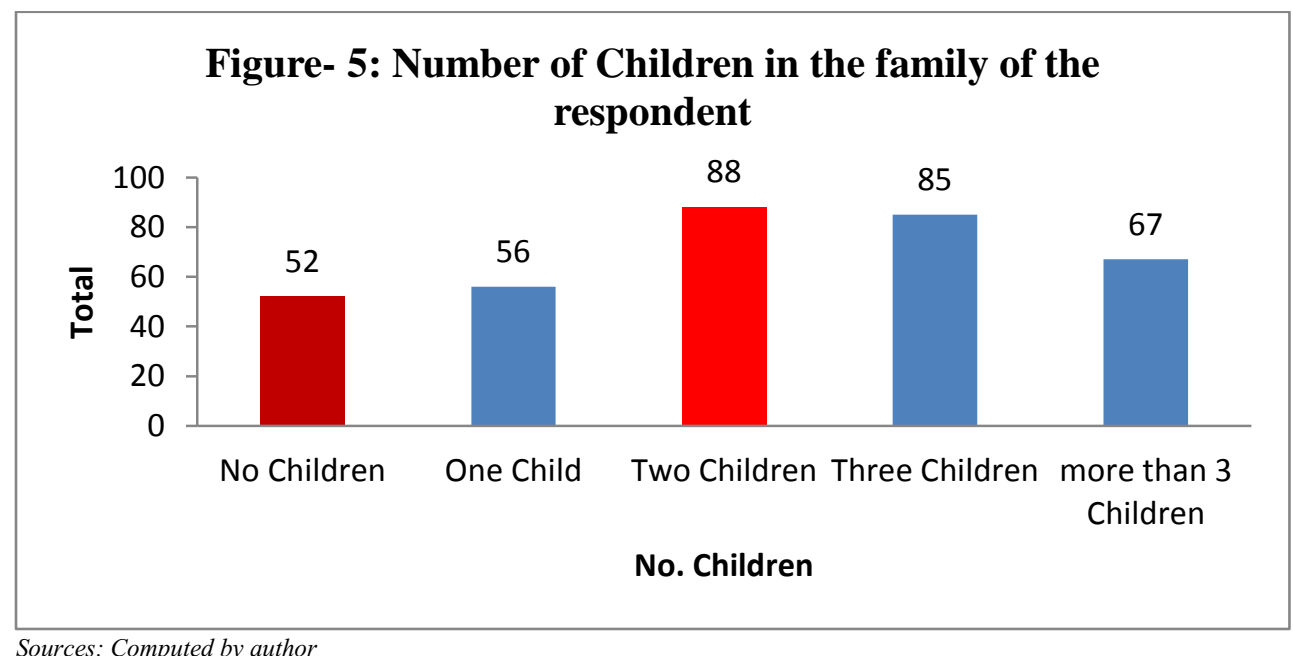


The number of children in the families of the respondents is depicted in the above table. It can be inferred from the table that $16.09 \%$ of families are having at least one child. On the contrary, $14.94 \%$ of the families are having no children in their home, $25.29 \%$ of families have two children followed by $24.43 \%$ of families having 3 children in their family. Finally, there are only $19.25 \%$ of families have more than 3 children. In total, there are $80.75 \%$ of respondents have children in their family.

\section{Earning members in the family of the respondents}

The table presented below shows the number of family members of the respondents who are working and earning money. Working members in a family is an important determinant of economic soundness. The higher the number of working members in a family the higher is the financial soundness. However, it can be moderated by the total number of family members. Therefore, the ratio of earning members to the total number of family members could be a true determinant of the financial viability of any household. From the table, it can also be observed that there is a maximum of 3 members in the group. The statistics for the male working members in a family indicates that there are $33.02 \%$ families or respondents who have 3 male working members, whereas, in the case of females it is zero. Similarly, $43.64 \%$ of families have two working male members; on the contrary, $34.75 \%$ of families are having two female members working and earnings for the family. It is also observed that 52 (14.94\%) respondents said that there are no working male members in their family, whereas, 115 (33.04\%) respondents said that they don't have working female members in their family.

Table-6: Total Earning Members in the Family

\begin{tabular}{|l|c|c|c|c|c|c|}
\hline & Male & $\begin{array}{c}\text { Total } \\
\text { Male }\end{array}$ & $\begin{array}{c}\text { Valid } \\
\text { Percent }\end{array}$ & Female & $\begin{array}{c}\text { Total } \\
\text { Female }\end{array}$ & $\begin{array}{c}\text { Valid } \\
\text { Percent }\end{array}$ \\
\hline No Earning Member & 52 & 0 & 0.00 & 115 & 0 & 0.00 \\
\hline 1 Member & 123 & 123 & 23.34 & 184 & 184 & 65.25 \\
\hline 2 Members & 115 & 230 & 43.64 & 49 & 98 & 34.75 \\
\hline 3 Members & 58 & 174 & 33.02 & 0 & 0 & 0.00 \\
\hline Total & 348 & 527 & 100.00 & 348 & 282 & 100.00 \\
\hline
\end{tabular}

Sources: Computed by author

On the other hand, the families having only one working male member is $123(23.34 \%)$, while, the families having one female member employed is 184 $(65.25 \%)$. The total working member information provided by the respondents reveal that there are a total of 527 male working members and 282 female working members in the households or respondents' family.

\section{The Income of the respondents}

The table given below shows the approximate income from Primary Occupation per Month. Some respondents are involved only in original Occupation, some in other cultivation and some respondents are doing both other and secondary cultivation as presented in the following headings. It can be observed from the income from Primary Occupation that the minimum amount of income is up to Rs.5000/- per month whereas; the maximum income is more than Rs.10000/per month. Similarly, the average income from primary cultivation has been estimated at nearly Rs.11721.26/per month. Where the majority of the respondents fall under the income group of Rs.7001/- to Rs.10000/- per month $(55.46 \%)$ and only $11.21 \%$ of the respondents could able to earn more than Rs.10000/- per month from Primary Occupation.

Table-7: Income from Primary Occupation per Month

\begin{tabular}{|c|c|c|}
\hline Income Group & Frequency & Per cent \\
\hline Not involved in Primary Occupation & 0 & Not included in the Percentage calculation \\
\hline upto 5000 & 14 & 4.02 \\
\hline $5001-7000$ & 102 & 29.31 \\
\hline $7001-10000$ & 193 & 55.46 \\
\hline More than 10000 & 39 & 11.21 \\
\hline Total Samples & 348 & 100.00 \\
\hline The average income per head & 11721.26 & \\
\hline * Some respondents are involved both in Primary and Secondary Occupation \\
\hline
\end{tabular}

Sources: Computed by author 
Table-8: Income from Secondary Occupation per Month

\begin{tabular}{|l|c|c|}
\hline Income Group & Frequency & Per cent \\
\hline $\begin{array}{l}\text { Not involved in } \\
\text { Secondary Occupation }\end{array}$ & 64 & Not included in the Percentage calculation \\
\hline upto 5000 & 36 & 12.68 \\
\hline $5001-7000$ & 195 & 68.66 \\
\hline $7001-10000$ & 53 & 18.66 \\
\hline More than 10000 & 0 & 0.00 \\
\hline Total Samples & 284 & 100.00 \\
\hline The average income per head & 8366.93 & \\
\hline * Some respondents are involved both in Secondary and Primary Occupation \\
\hline
\end{tabular}

Similarly, in the case of Secondary Occupation per Month, the income grouping is identically distributed as in Primary cultivation. But the majority of the respondents in primary cultivation fall under the income group of Rs. 5001/- to Rs. 7000/- (68.66\%).
The average income from other cultivation has been estimated at Rs. 8366.93/- per month. As such, the number of respondents earning more than Rs. 7000/per month from Secondary cultivation is $18.66 \%$.

\section{Work Activity of the respondents}

Table-9: Grouping of Respondent according to their Work Activity

\begin{tabular}{|l|c|c|c|c|}
\hline \multicolumn{1}{|c|}{ Respondent Group } & Frequency & Per cent & $\begin{array}{c}\text { Valid } \\
\text { Percent }\end{array}$ & $\begin{array}{c}\text { Cumulative } \\
\text { Percent }\end{array}$ \\
\hline Working in Own Field & 91 & 26.15 & 26.15 & 26.15 \\
\hline Working in others Field as Labour & 140 & 40.23 & 40.23 & 66.38 \\
\hline Working in Own and Others field & 117 & 33.62 & 33.62 & 100.00 \\
\hline Total & 348 & 100.00 & 100.00 & \\
\hline
\end{tabular}

Sources: Computed by author

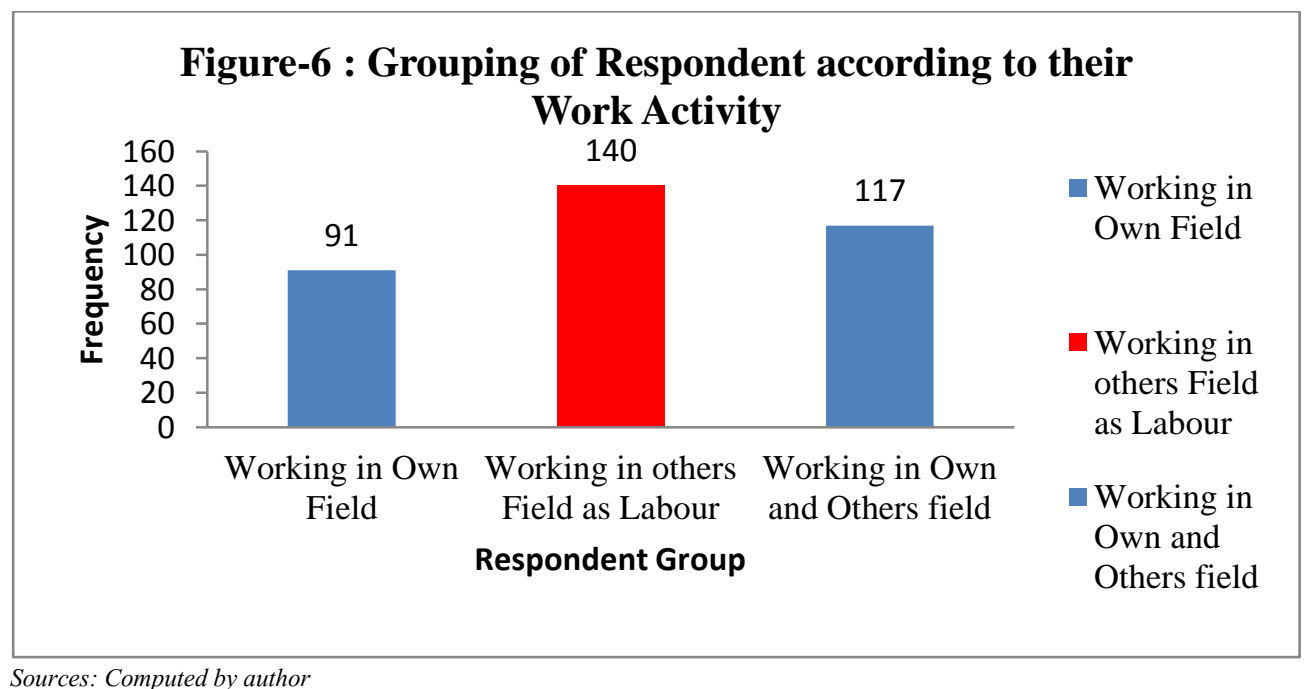

The above table and Figure show the different activities that the respondents are engaged in. It can be noted that most of the respondents are marginal farmers who possess low landholding up to one acre and some of them don't even have their land as they are engaged as labourers to earn their livelihood. There are $26.15 \%$ of the respondents are working in their land. $40.23 \%$ of the respondents are working in their land, as well as, working in others field as labourers. On the contrary,
$33.62 \%$ of the respondents don't have their land and work in others field as labour.

\section{Assets Owned by the respondents}

The following table shows the asset holding information of the households or respondents who had participated in the survey. There are eight different types of assets listed in the questionnaire. These are own house, television, radio, bicycle, motorcycle, 
mobile phone, livestock such as chicken, duck, goat, cow, buffalo, etc., and land.

Table-10a: Number of Status indicative Assets Owned by the respondents

\begin{tabular}{|c|c|c|c|c|}
\hline $\begin{array}{c}\text { Number of Assets } \\
\text { Holding }\end{array}$ & Frequency & $\begin{array}{c}\text { Contribution } \\
\mathbf{\%}\end{array}$ & Valid Percent & $\begin{array}{c}\text { Cumulative } \\
\text { Percent }\end{array}$ \\
\hline 1 Asset & 39 & 11.21 & 11.21 & 11.21 \\
\hline 2 Assets & 33 & 9.48 & 9.48 & 20.69 \\
\hline 3 Assets & 41 & 11.78 & 11.78 & 32.47 \\
\hline 4 Assets & 44 & 12.64 & 12.64 & 45.11 \\
\hline 5 Assets & 52 & 14.94 & 14.94 & 60.06 \\
\hline 6 Assets & 57 & 16.38 & 16.38 & 76.44 \\
\hline 7 Assets & 45 & 12.93 & 12.93 & 89.37 \\
\hline 8 Assets & 37 & 10.63 & 10.63 & 100.00 \\
\hline Total & 348 & 100.00 & 100.00 & \\
\hline
\end{tabular}

The asset holding pattern given in the table above indicates that only $10.63 \%$ of the respondents have all the eight number of assets listed in the questionnaire. On the contrary, nearly $11.21 \%$ of respondents possess only one kind of asset at their home. It can be further inferred that a higher number of households have four to six number of assets. $12.64 \%$ of respondents have five number assets compared to $14.94 \%$ having six and $16.38 \%$ having seven number assets owned. Similarly, only $9.48 \%$ have two numbers of assets and nearly $11.78 \%$ are having three assets at home.
When the respondents were asked about their recent purchase of any kind of assets listed in the questionnaire and the responses obtained indicate that there is a maximum of three assets bought recently by the respondents. It can be observed from the table given below that around $31.03 \%$ of households did not purchase any kind of asset recently means within 12 months. It can also be concluded from the data given in the table that only $36.78 \%$ of respondents have bought at least two assets in the past year.

Table-10b: Number of Status indicative Assets bought recently in the last twelve months by the Respondents

\begin{tabular}{|l|c|c|c|c|}
\hline \multicolumn{1}{|c|}{ Number of Assets } & Frequency & Contribution \% & Valid Percent & $\begin{array}{c}\text { Cumulative } \\
\text { Percent }\end{array}$ \\
\hline No Asset Bought & 108 & 31.03 & 31.03 & 31.03 \\
\hline One Asset Bought & 112 & 32.18 & 32.18 & 63.22 \\
\hline Two Assets Bought & 128 & 36.78 & 36.78 & 100.00 \\
\hline Total & 348 & 100.00 & 100.00 & \\
\hline
\end{tabular}

Sources: Computed by author

The following table shows the list of total assets bought by the respondents in the last 12 months and the total number of assets owned at the time of the survey.

Table-10c: Pattern of Asset holding by the respondent's total figure

\begin{tabular}{|c|c|c|}
\hline Asset Type & Total Household Assets & Percentage \\
\hline Own House & 348 & 21.32 \\
\hline TV & 250 & 15.32 \\
\hline Radio & 65 & 3.98 \\
\hline Bicycle & 250 & 15.32 \\
\hline Motorcycle & 95 & 5.82 \\
\hline Mobile Phone & 450 & 27.57 \\
\hline Live Stock & 54 & 3.31 \\
\hline Land & 120 & 7.35 \\
\hline Total & 1632 & \\
\hline
\end{tabular}

Sources: Computed by author 


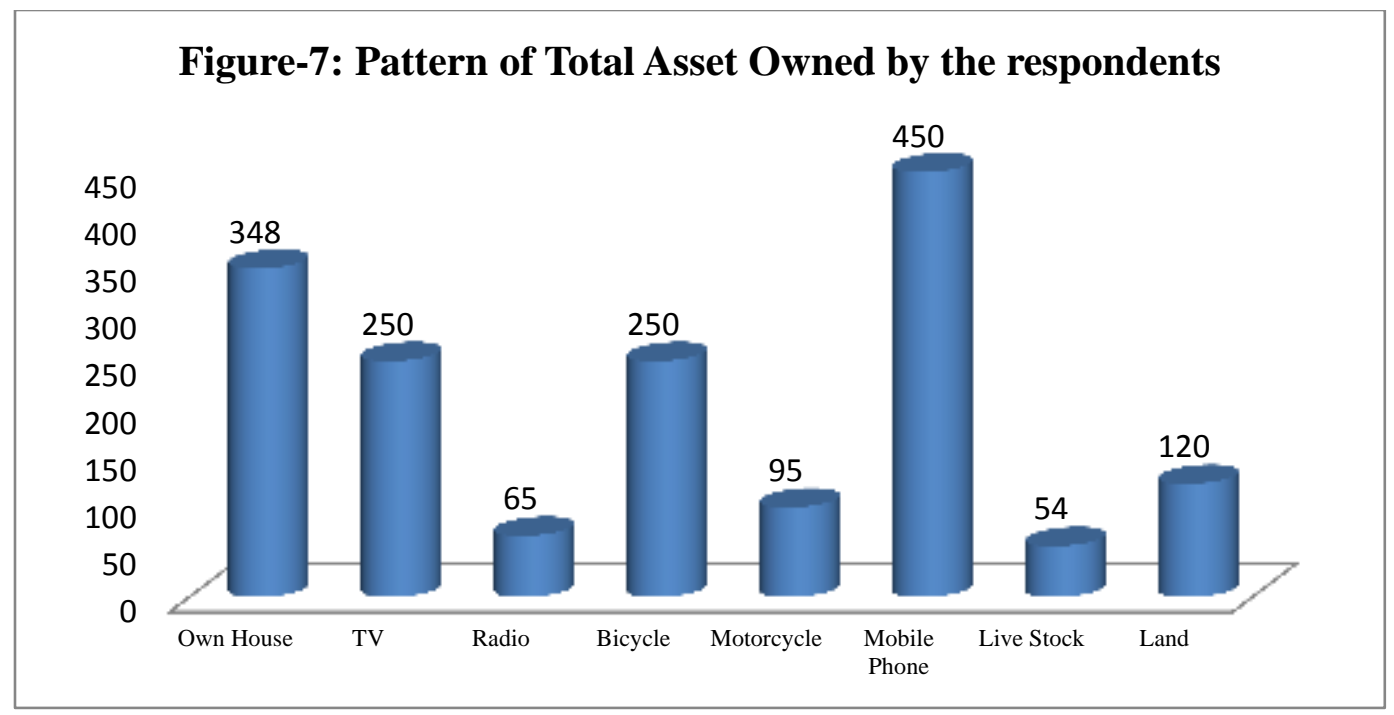

Sources: Computed by author

It can be observed from the above presentation of data regarding the types of assets owned by the respondents that mobile phone is one of the assets owned by a maximum number of households followed by land and own house. Similarly, a similar pattern of ownership has been observed for the assets like television, livestock and bicycle. The number of respondents having a motorcycle is $40.5 \%$ which is the lowest in the group. On the other hand, $44.17 \%$ of respondents are having transistor radio at home. It is one of the important assets for the farmers because it is a very cost-effective element to remain informed about the cultivation and weather-related information along with entertainment.

Further, it can be observed that bicycle and mobile phone are the two assets bought recently in the last year. There are $30.67 \%$ recent purchase of a bicycle and $26.33 \%$ of a mobile phone. Similarly, $11.33 \%$ and $10.83 \%$ of respondents have bought a TV and a Motorcycle recently. On the contrary, no one has purchased a house or cultivation land recently in the last 12 months.

\section{House ownership category}

Table-11: House Ownership Category

\begin{tabular}{|l|c|c|c|c|}
\hline House Ownership & Frequency & $\begin{array}{c}\text { Contribution } \\
\text { \% }\end{array}$ & $\begin{array}{c}\text { Valid } \\
\text { Percent }\end{array}$ & $\begin{array}{c}\text { Cumulative } \\
\text { Percent }\end{array}$ \\
\hline Self-Made Own House & 152 & 43.68 & 43.68 & 43.68 \\
\hline Rented House & 20 & 5.75 & 5.75 & 49.43 \\
\hline Govt. Provided Own House & 176 & 50.57 & 50.57 & 100.00 \\
\hline Total & 348 & 100.00 & 100.00 & \\
\hline
\end{tabular}

Sources: Computed by author

Figure-8: House Ownership Category

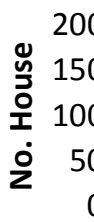

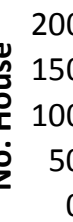

Self-Made Own

House

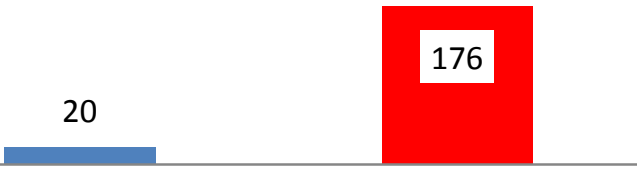

Rented House

Govt. Provided Own

House

House Ownership 
The above table shows the distribution of respondents according to their ownership of houses. This ownership has been divided into three categories such as; purely own house, rented house and house constructed using government financial support like Indira Awasha Scheme and Biju Pakka Ghara Yojana which is termed as government-provided own house. It is observed that $43.68 \%$ of respondents have their own house constructed without any financial support from the government. Whereas, $50.57 \%$ of respondents have their house constructed using government financial support. Finally, 5.75\% of respondents don't have their own house and live in rented houses. It can further be inferred that $43.68 \%$ of respondents are having their own house compared to $49.43 \%$ who do not own a house.

\section{Type of House}

Table-12: Type of House

\begin{tabular}{|c|c|c|c|c|}
\hline Groups & Frequency & Contribution \% & Valid Percent & Cumulative Percent \\
\hline Kuchha & 62 & 17.82 & 17.82 & 17.82 \\
\hline Semi Pucca & 104 & 29.89 & 29.89 & 47.70 \\
\hline Pucca & 182 & 52.30 & 52.30 & 100.00 \\
\hline Total & 348 & 100.00 & 100.00 & \\
\hline
\end{tabular}

Sources: Computed by author

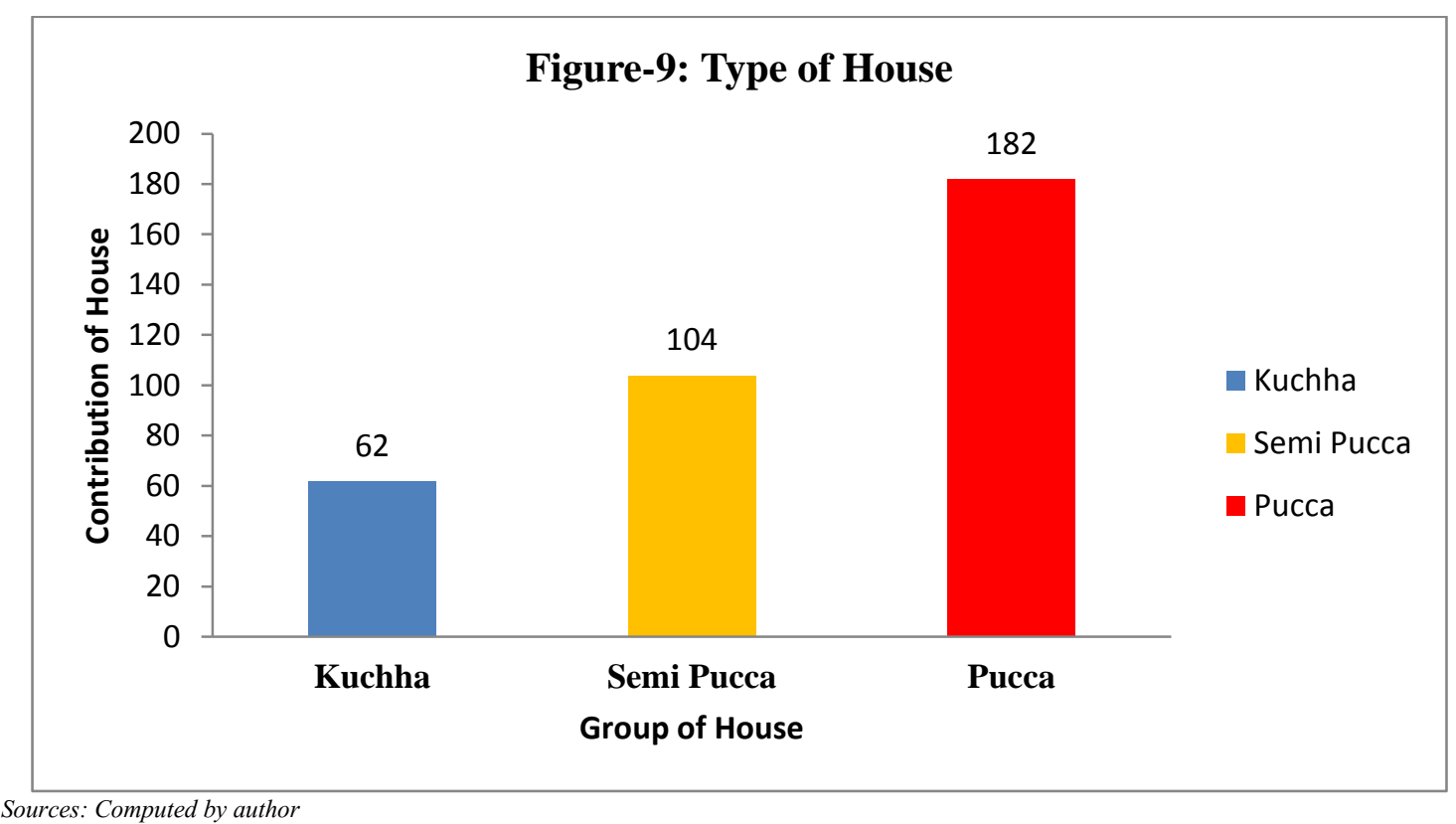

Sources: Computed by author

The above table indicates the distribution of the type of house owned by the respondents. It is seen that most of the people have kuchha and semi-pucca house compared to a pucca house. $17.82 \%$ of respondents are having a kuchha house, $52.30 \%$ of respondents said that they have a pucca house compared to $29.89 \%$ of respondents having a pucca house.

Fuel for Cooking used by the Respondents

Table-13: Fuel for Cooking used by the Respondents

\begin{tabular}{|c|c|c|c|c|}
\hline Cocking Fuel & Frequency & Contribution $\%$ & Valid Percent & Cumulative Percent \\
\hline Fire Wood & 75 & 21.55 & 21.55 & 21.55 \\
\hline Kerosene & 16 & 4.60 & 4.60 & 26.15 \\
\hline LPG & 177 & 50.86 & 50.86 & 77.01 \\
\hline Both Fire Wood and LPG & 80 & 22.99 & 22.99 & 100.00 \\
\hline Total & 348 & 100.00 & 100.00 & \\
\hline
\end{tabular}




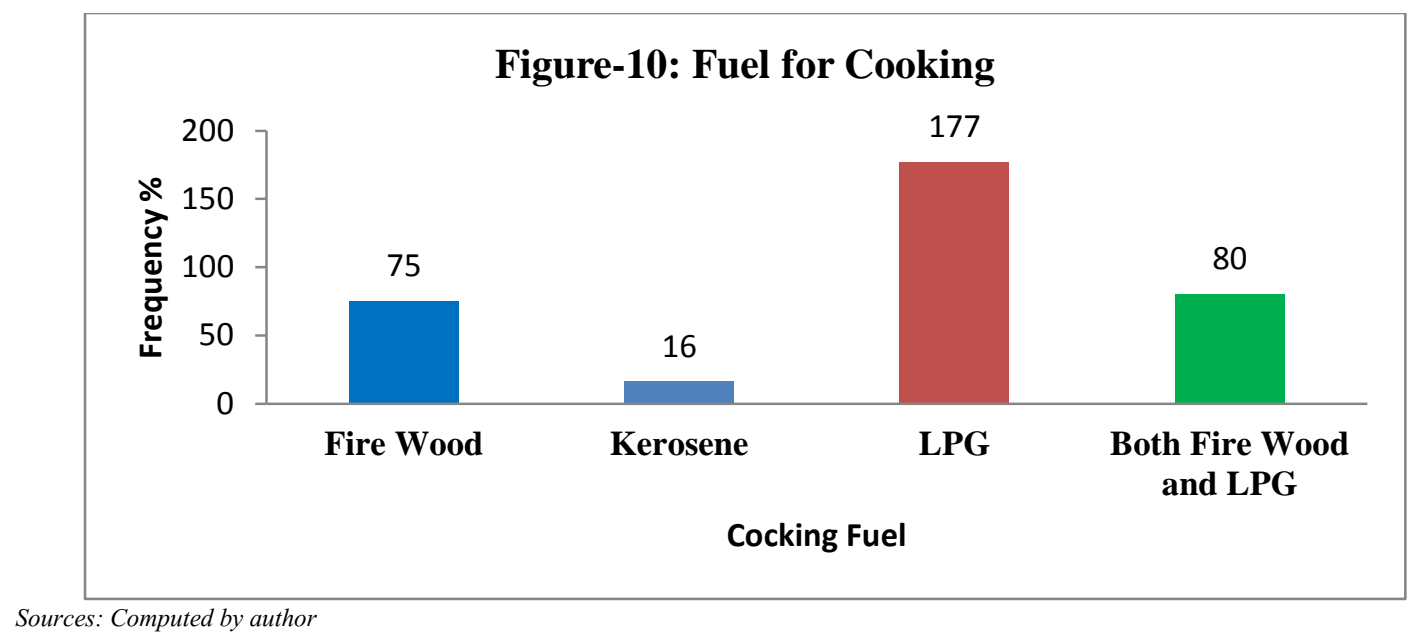

The use of fuel for cooking is a significant indicator of the economic status of the people in Odisha. Many people who live below the poverty line don't have excess to clean fuel like LPG and some of them even don't have kerosene stoves either. From the primary information collected for the survey, it is estimated that still there are a large number of households who rely on firewood for cooking and they represent $21.55 \%$ of the total households in the survey. It is also observed that there are $4.60 \%$ of respondents use kerosene oil stoves for cooking and only $50.86 \%$ of the respondents do have LPG stoves at home. It has also been observed in the survey that most people use multiple fuels for cooking though they have LPG they still use firewood or kerosene for cooking. This data only presents the extensive use of kinds of fuel by the households, whereas, the respondents who have an LPG connection considered it as economically viable compared to the other two categories.

\section{Economic status indicating elements owned by the respondents}

Table-14: List of different Economic status indicating elements owned by the respondents

\begin{tabular}{|l|c|c|c|c|c|}
\hline Economic Status & Yes & Yes \% & No & No \% & Total \\
\hline Electricity Supply & 270 & 77.59 & 78 & 22.41 & 348 \\
\hline Water Facility & 156 & 44.83 & 192 & 55.17 & 348 \\
\hline Children's education & 218 & 62.64 & 130 & 37.36 & 348 \\
\hline Bank Account & 303 & 87.07 & 45 & 12.93 & 348 \\
\hline Voter and Aadhar ID & 248 & 71.26 & 100 & 28.74 & 348 \\
\hline Live Stock & 98 & 28.16 & 250 & 71.84 & 348 \\
\hline Indebtedness & 180 & 51.72 & 168 & 48.28 & 348 \\
\hline Loan Frequency & 190 & 54.60 & 158 & 45.40 & 348 \\
\hline Health Insurance & 56 & 16.09 & 292 & 83.91 & 348 \\
\hline Mosquito Net & 53 & 15.23 & 295 & 84.77 & 348 \\
\hline Toilet Facility & 156 & 44.83 & 192 & 55.70 & 348 \\
\hline
\end{tabular}

Sources: Computed by author 


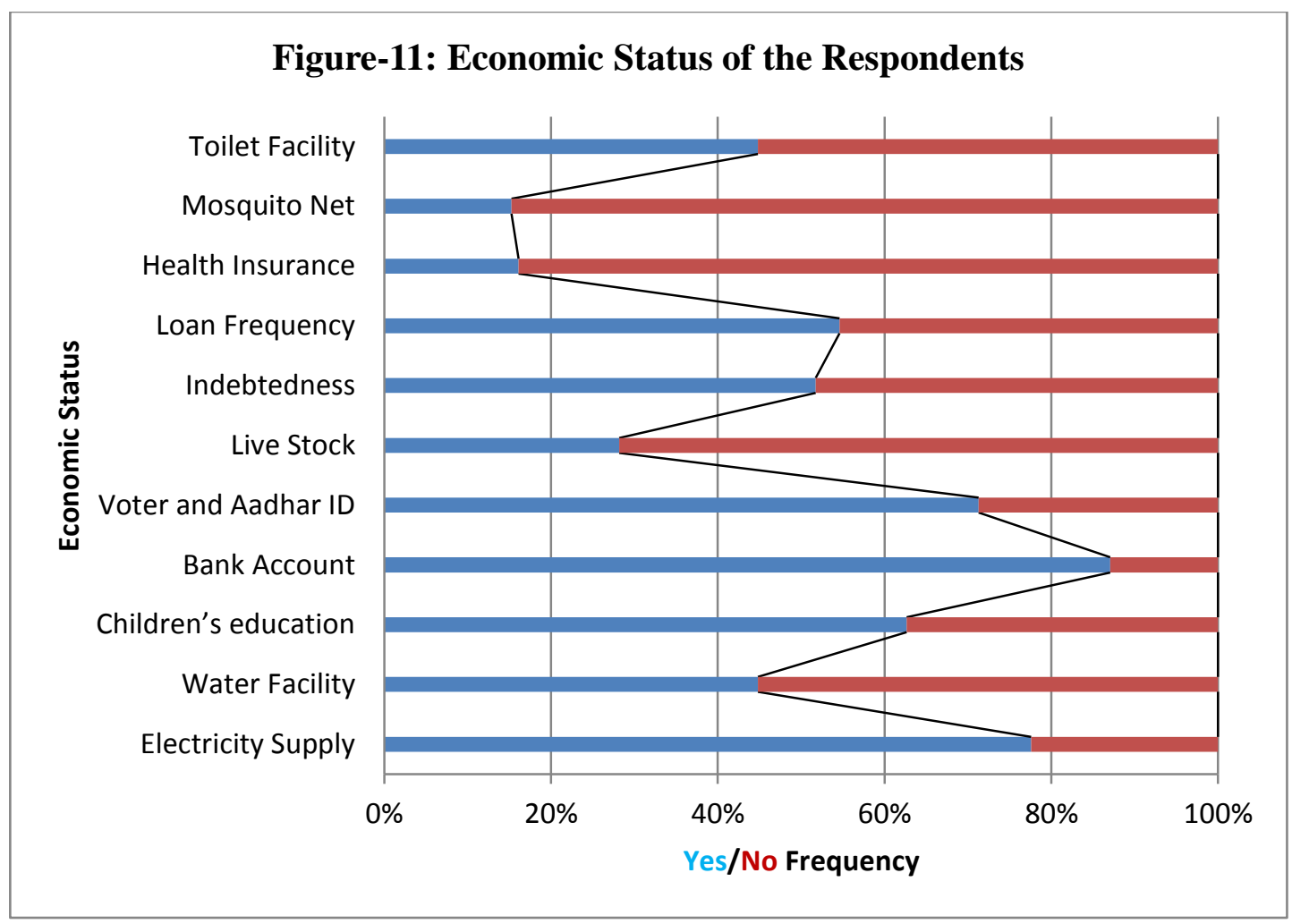

Sources: Computed by author

The above table shows the economic status indicators of the respondents that have been further used to estimate the level of living or standard of living of the respondents. Electricity, water supply to houses or sources of drinking water, education of the children who have attained the age of five years, bank accounts, voter ID card, livestock, indebtedness and frequency of taking a loan for different purpose etc. are vital indicators that influence the financial or economic status of a person. It is observed that there are $77.59 \%$ of respondents have electricity supply to their houses, whereas, 22.41 per cent of the respondents don't have electricity supply at all. Similarly, only $44.83 \%$ of the respondents have their source of drinking water like a well or municipality water supply compared to $55.17 \%$ of the respondents who depend on public sources to meet their daily water requirements.

Additionally, it is also observed that $62.64 \%$ of the respondents are providing education to their children and the rest of $37.36 \%$ of respondents don't have children that's why they said they don't have any children in school. Again, $12.93 \%$ of respondents don't have a bank account compared to $87.07 \%$ who have a bank account mostly Janadhan accounts. As such, there are only $8.66 \%$ of respondents who don't have a voter/Aadhar ID card but impressively there are $71.26 \%$ of respondents who have a voter/Aadhar ID card. As far as livestock ownership is concerned $28.74 \%$ of respondents own some livestock, whereas, $71.84 \%$ of the respondents don't have any livestock.

The indebtedness position indicates whether any respondent has taken any kind of loan at the time of the survey. $54.60 \%$ of the respondents said that they have a loan on their head presently, whereas, $45.40 \%$ of the respondents said that they don't have any loan in their hand as such. The frequency of indebtedness indicates the frequency of taking loans for different purposes. There are $55 \%$ of the respondents who replied that they take loan frequently for different purposes, whereas, $45 \%$ of the respondents take loan occasionally or rarely for any special purpose like marriage or medical emergency etc.

\section{Indebtedness or Debt position of the respondents}

Table-15: Grouping of the Respondents according to their Indebtedness

\begin{tabular}{|l|c|c|c|c|}
\hline \multicolumn{1}{|c|}{ Loan Group } & Frequency & Contribution \% & Valid Percent & Cumulative Percent \\
\hline No Loan Taken & 50 & 14.37 & 14.37 & 14.37 \\
\hline Up to 3000 & 59 & 16.95 & 16.95 & 31.32 \\
\hline $3001-6000$ & 68 & 19.54 & 19.54 & 50.86 \\
\hline
\end{tabular}




\begin{tabular}{|l|c|c|c|c|}
\hline $6001-9000$ & 53 & 15.23 & 15.23 & 66.09 \\
\hline $9001-12000$ & 63 & 18.10 & 18.10 & 84.20 \\
\hline More than 12000 & 55 & 15.80 & 15.80 & 100.00 \\
\hline Total & 348 & 100.00 & 100.00 & \\
\hline
\end{tabular}

Sources: Computed by author

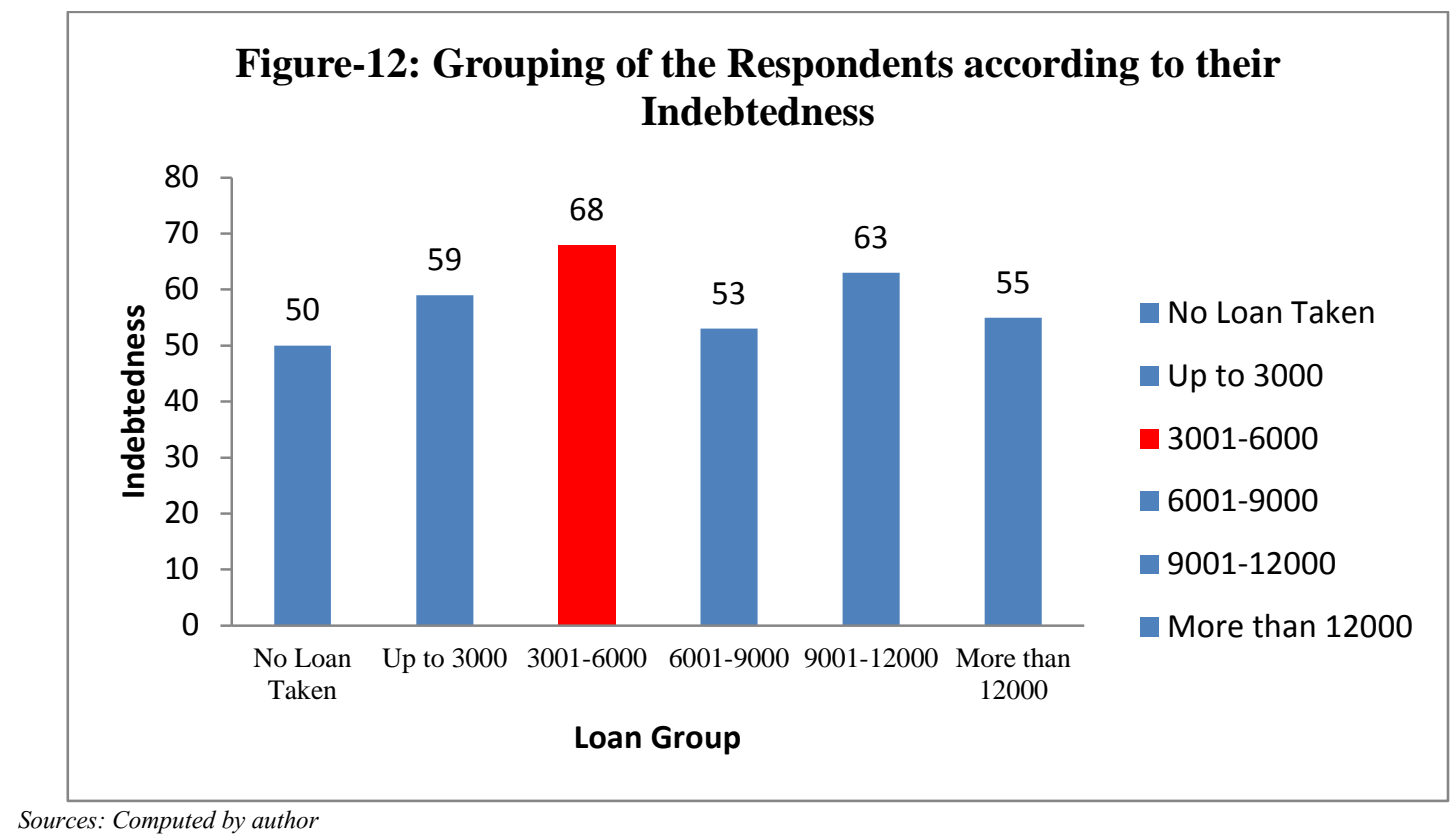

The above table and figure present the information regarding the amount of loan taken by the respondents. It can be observed that 50 respondents do not have any loan in hand at the time of interview for the survey. However, there are $59(16.95 \%)$ of the total respondents have at least a 30,00 rupees loan in hand. Similarly, $68(19.54 \%)$ of the respondents have a loan ranging from 30,00 to 60,00 rupees. The number of respondents with a loan between Rs.60, 00 to 90,00 is only 53 i.e. $15.26 \%$ of the total respondents. Further, 63 $(18.10 \%)$ of the respondents have taken a loan ranging from 90, 00 to 1, 20, 00 rupees. Finally, the number of respondents having a loan of more than 1, 20, 00 rupees is 55 i.e. $15.80 \%$. In other words, it can be estimated that the number of respondents who have a loan of more than 60,00 rupees is 53 i.e. $15.23 \%$ compared to the respondents having a loan to the tune of 60,00 is 63 $(19.54 \%)$.

\section{Health care expenditure in Household in Khallikote Block}

Table-16: Health care expenditure of households

\begin{tabular}{|c|c|c|c|c|c|}
\hline Expenditure for Medical & Yes & Yes \% & No & No \% & Total \\
\hline Medical treatment & 280 & 80.46 & 68 & 19.54 & $100 \%$ \\
\hline Government Hospital & 156 & 44.83 & 192 & 55.17 & $100 \%$ \\
\hline Food accommodation & 300 & 86.21 & 48 & 13.79 & $100 \%$ \\
\hline Medicines fees & 223 & 64.08 & 125 & 35.92 & $100 \%$ \\
\hline Travelling & 348 & 100.00 & 0 & 0.00 & $100 \%$ \\
\hline Doctors fee & 192 & 55.17 & 156 & 44.83 & $100 \%$ \\
\hline Bed charge & 53 & 15.23 & 295 & 84.77 & $100 \%$ \\
\hline Diagnostics charge & 248 & 71.26 & 100 & 28.74 & $100 \%$ \\
\hline Health Insurance & 100 & 28.74 & 248 & 71.26 & $100 \%$ \\
\hline
\end{tabular}




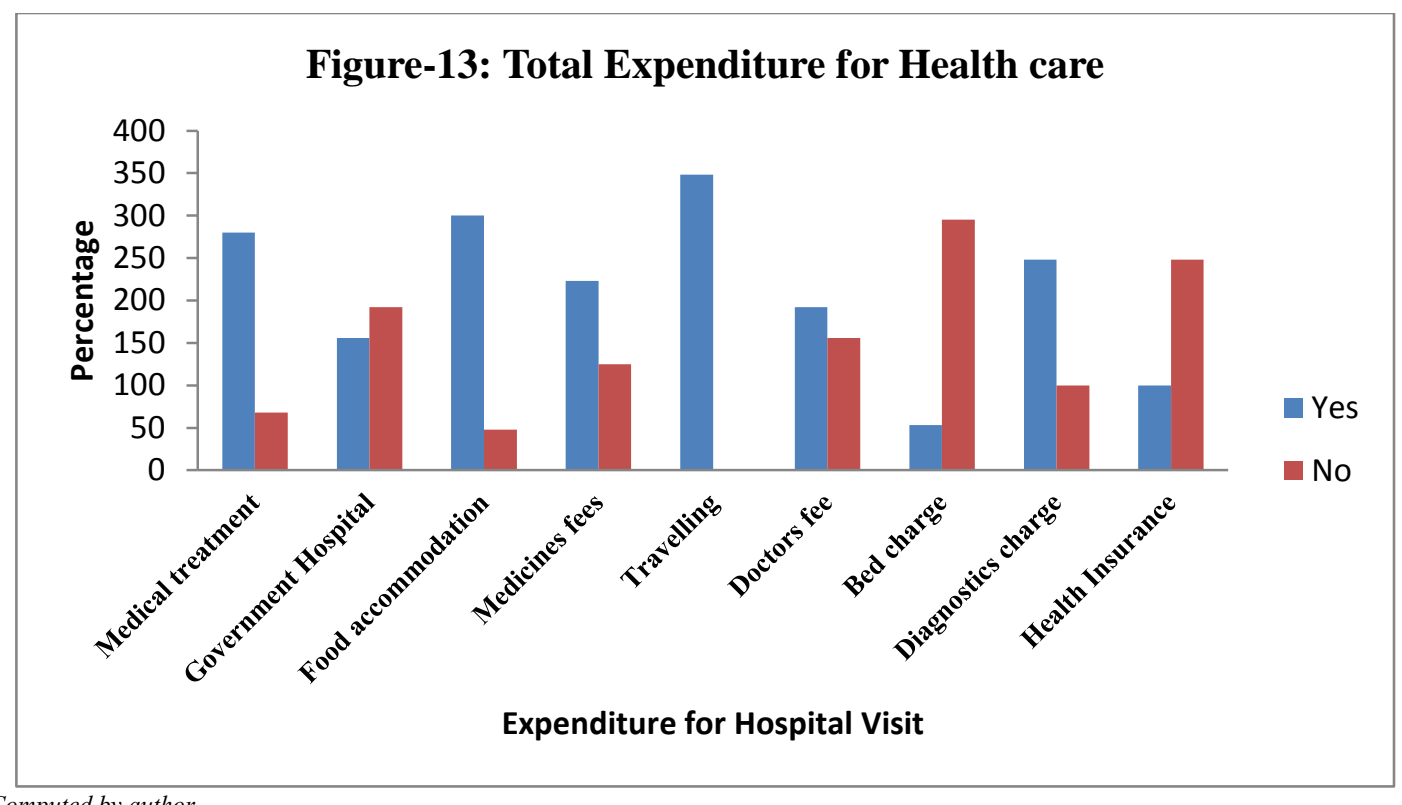

Sources: Computed by author

according to National Health Policy, the government of

It may be mentioned here that the general norm of population coverage by a primary health centre Odisha (2011). As per that norm, both Langaleswar and Kumarsing are overburdened.

Table-17: Socio-economic and demographic characteristics of the sample households

\begin{tabular}{|c|c|c|c|c|}
\hline & ST & SC & OBC & Total \\
\hline Sample Households & 116 & 116 & 116 & 348 \\
\hline Total Sample household Members & 350 & 520 & 627 & 1497 \\
\hline$\%$ of female-headed HH Education of HH head & 15.5 & 17.1 & 20.9 & 18.6 \\
\hline No education & 77.1 & 36.8 & 19.1 & 26.3 \\
\hline Primary & 12.8 & 19.6 & 32.2 & 22.1 \\
\hline High School & 9.6 & 44.4 & 46.2 & 49.1 \\
\hline Above high school & 1.2 & 2.5 & 7.6 & 3.4 \\
\hline \multicolumn{5}{|c|}{ Landholdings } \\
\hline No land & 2.6 & 89.6 & 1.2 & 52.3 \\
\hline \multicolumn{5}{|c|}{ Occupation } \\
\hline Independent Cultivator & 3.7 & 28.2 & 31.2 & 39.3 \\
\hline Wage labour & 93.6 & 62.1 & 53.6 & 49.1 \\
\hline Govt./Private Service & 1.2 & 1.6 & 18.1 & 13.2 \\
\hline Others & 5.6 & 7.9 & 13.2 & 9.2 \\
\hline Mean per capita consumption expenditure & 5213 & 5738 & 6213 & 7100 \\
\hline $95 \% \mathrm{CI}$ & 4463,5701 & 6048,8219 & 6031,7023 & 6514,7321 \\
\hline Mean household Size & 5.6 & 5.2 & 5.9 & 5.6 \\
\hline $95 \% \mathrm{CI}$ & $5.2,6.1$ & $6.4,5.4$ & $5.6,6.2$ & $5.2,5.5$ \\
\hline Households with elderly member (\%) & 33.1 & 32.7 & 39.7 & 46.5 \\
\hline Households with chronically ill member (\%) & 28.4 & 61.9 & 62.3 & 59.9 \\
\hline \multicolumn{5}{|c|}{ Level of health care need (column-wise \% distribution) } \\
\hline Low & 26 & 29 & 27 & 30 \\
\hline High & 67 & 59 & 47 & 54 \\
\hline Very high & 8 & 12 & 27 & 16 \\
\hline \multicolumn{5}{|l|}{ Share of the private sector (\%) } \\
\hline Total hospital visits & 52.8 & 66.3 & 71.7 & 65.1 \\
\hline Total hospitalisations & 70.2 & 80.6 & 80.2 & 77.1 \\
\hline
\end{tabular}

Sources: Computed by author 
Table-17 shows the socioeconomic, demographic, and health status profiles of the survey households. Caste is a good stratification variable for classifying social class households based on social, economic, and demographic characteristics, as seen in the table. Maleheaded households are much more frequent in the Khallikote Block of socially backward castes (SC, ST, and $\mathrm{OBC}$ ). The distribution of land, the most important economic asset, reveals that most people in the Khallikote block study area are landless. In the same manner, caste groups' consumption expenditures differed about health expenditure. The OBC, other SC, and ST have the highest health expenditure, while the $\mathrm{OBC}$, other SC, and ST have the lowest.

The health care expenditure of households with various levels of health care need validates our need-based identification of households. Besides that, a household's choice of healthcare providers may impact its healthcare spending, as hospital visits to government and private informal providers are less expensive than visits to formal private providers. If caste differences in healthcare expenditure were extremely common and individuals didn't need it, one would expect to see a similar pattern of caste differences among low, medium, and high-need households.

\section{The Problems faced by the social class groups are gender-specific of Health care expenditure and income-earning of households.}

The relationship between the gender of the respondents and the problems faced by the social class workers. T-test has been the widely used method to examine the mean difference between any two groups whether they are dependent or independent on each other. Here, the independent samples t-test is found to be appropriate because the primary data follows the assumptions specified for the particular test. The normality and homogeneity tests have been initially conducted to find out the appropriateness of the data for the t-test. The following figures give the normality of test results. It can be observed that the data is quite convincing as far as the normality criteria are concerned.

Table-18: Tests of Normality

\begin{tabular}{|c|c|c|c|c|c|c|c|}
\hline & Gender & \multicolumn{3}{|c|}{ Kolmogorov-Smirnova } & \multicolumn{3}{|c|}{ Shapiro-Wilk } \\
\cline { 3 - 8 } & & Statistic & df & Sig. & Statistic & df & Sig. \\
\hline \multirow{2}{*}{ Health care Expenditure } & Male & .13 & 208 & .00 & .94 & 208 & .00 \\
\cline { 2 - 8 } & Female & .18 & 140 & .00 & .92 & 140 & .00 \\
\hline \multirow{2}{*}{ Total income of HHs } & Male & .13 & 208 & .00 & .94 & 208 & .00 \\
\cline { 2 - 8 } & Female & .18 & 140 & .00 & .92 & 140 & .00 \\
\hline \multicolumn{8}{|c|}{ a. Lilliefors Significance Correction } \\
\hline
\end{tabular}

Sources: Computed by author

Figure-14: Test of Normality

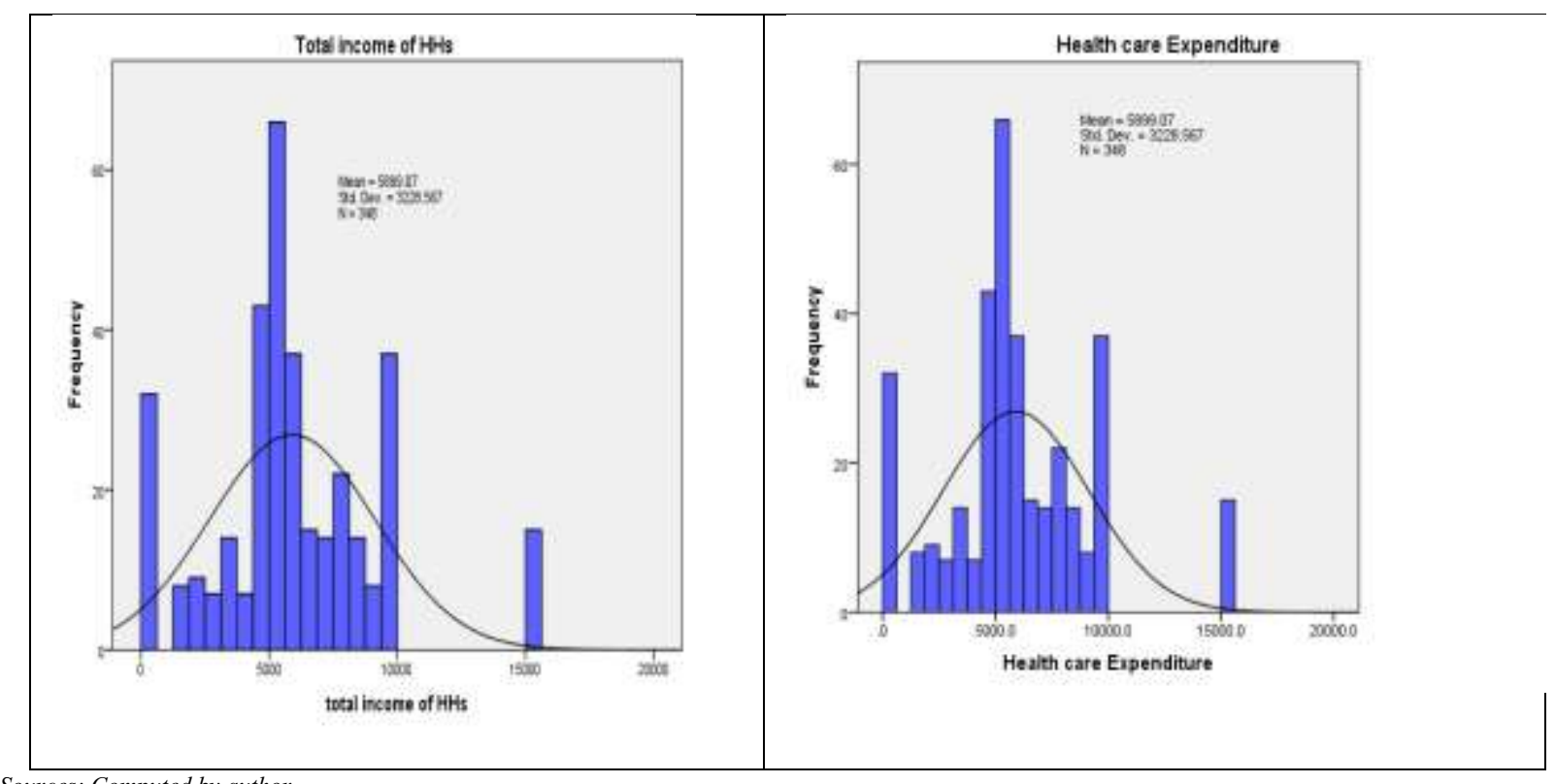

Sources: Computed by author 
Now the t-test gives two tables that are given below. This table is the group statistics and the second table is about Levene's test for homogeneity and the independent samples t-test. In this case, the groups are male and female earning of the income and the expenditure in health care problems. From the group statistics, it can be noticed that the number of female respondents is 208 and male respondents are 140. The mean and standard deviation for each group has been given in the table. It can be noted that in the case of health care expenditure the mean of the female respondents is 5629.83 and for male, is 6080.28 with a standard deviation of 3261.56 and 3201.27 respectively. Similarly, in the case of the Total income of the households, the mean of problems for a female is 5629.84 with a standard deviation of 3261.56 and a male is 6080.29 with 3201.27 a standard deviation.

Table-19: Independent Samples Test of Case Processing Summary

\begin{tabular}{|c|c|c|c|c|c|c|c|}
\hline & \multirow[t]{3}{*}{ Gender } & \multicolumn{6}{|c|}{ Cases } \\
\hline & & \multicolumn{2}{|c|}{ Valid } & \multicolumn{2}{|c|}{ Missing } & \multicolumn{2}{|c|}{ Total } \\
\hline & & $\mathrm{N}$ & Per cent & $\mathrm{N}$ & Per cent & $\mathrm{N}$ & Per cent \\
\hline \multirow[t]{2}{*}{ Health care Expenditure } & Male & 208 & $100.0 \%$ & 0 & $0.0 \%$ & 208 & $100.0 \%$ \\
\hline & Female & 140 & $100.0 \%$ & 0 & $0.0 \%$ & 140 & $100.0 \%$ \\
\hline \multirow[t]{2}{*}{ Total income of HHs } & Male & 208 & $100.0 \%$ & 0 & $0.0 \%$ & 208 & $100.0 \%$ \\
\hline & Female & 140 & $100.0 \%$ & 0 & $0.0 \%$ & 140 & $100.0 \%$ \\
\hline
\end{tabular}

Sources: Computed by author

Table-20: Descriptive Statistics of class groups are gender-specific of Health care and income-earning of households

\begin{tabular}{|c|c|c|c|c|c|}
\hline & \multicolumn{3}{|c|}{ Gender } & Statistic & Std. Error \\
\hline \multirow{20}{*}{$\begin{array}{l}\text { Health care } \\
\text { Expenditure }\end{array}$} & \multirow[t]{10}{*}{ Male } & \multicolumn{2}{|l|}{ Mean } & 6080.29 & 221.97 \\
\hline & & \multirow{2}{*}{$\begin{array}{l}95 \% \text { Confidence Interval } \\
\text { for Mean }\end{array}$} & Lower Bound & 5642.68 & \\
\hline & & & Upper Bound & 6517.90 & \\
\hline & & \multicolumn{2}{|c|}{\begin{tabular}{|c|} 
Std. Deviation \\
\end{tabular}} & 3201.28 & \\
\hline & & \multicolumn{2}{|c|}{ Minimum } & 300.00 & \\
\hline & & \multicolumn{2}{|c|}{ Maximum } & 15000.00 & \\
\hline & & \multicolumn{2}{|c|}{ Range } & 14700.00 & \\
\hline & & \multicolumn{2}{|c|}{ Interquartile Range } & 3333.00 & \\
\hline & & \multicolumn{2}{|c|}{ Skewness } & 0.55 & 0.17 \\
\hline & & \multicolumn{2}{|c|}{ Kurtosis } & 0.93 & 0.34 \\
\hline & \multirow[t]{10}{*}{ Female } & \multicolumn{2}{|c|}{ Mean } & 5629.84 & 275.65 \\
\hline & & \multirow{2}{*}{$\begin{array}{c}95 \% \text { Confidence Interval } \\
\text { for Mean }\end{array}$} & Lower Bound & 5084.82 & \\
\hline & & & Upper Bound & 6174.85 & \\
\hline & & \multicolumn{2}{|c|}{\begin{tabular}{|c|} 
Std. Deviation \\
\end{tabular}} & 3261.56 & \\
\hline & & \multicolumn{2}{|c|}{ Minimum } & 300.00 & \\
\hline & & \multicolumn{2}{|c|}{ Maximum } & 15000.00 & \\
\hline & & \multicolumn{2}{|c|}{ Range } & 14700.00 & \\
\hline & & \multicolumn{2}{|c|}{ Interquartile Range } & 3289.00 & \\
\hline & & \multicolumn{2}{|c|}{ Skewness } & 0.75 & 0.21 \\
\hline & & \multicolumn{2}{|c|}{ Kurtosis } & 1.20 & 0.41 \\
\hline \multirow[t]{10}{*}{ Total income of HHs } & \multirow[t]{10}{*}{ Male } & \multicolumn{2}{|l|}{ Mean } & 6080.29 & 221.97 \\
\hline & & \multirow{2}{*}{$\begin{array}{c}95 \% \text { Confidence Interval } \\
\text { for Mean }\end{array}$} & Lower Bound & 5642.68 & \\
\hline & & & Upper Bound & 6517.90 & \\
\hline & & \multicolumn{2}{|c|}{\begin{tabular}{|c|} 
Std. Deviation \\
\end{tabular}} & 3201.28 & \\
\hline & & \multicolumn{2}{|c|}{ Minimum } & 300 & \\
\hline & & \multicolumn{2}{|c|}{ Maximum } & 15000 & \\
\hline & & \multicolumn{2}{|c|}{ Range } & 14700 & \\
\hline & & \multicolumn{2}{|c|}{ Interquartile Range } & 3333 & \\
\hline & & Skewne & & 0.55 & 0.17 \\
\hline & & Kurtos & & 0.93 & 0.34 \\
\hline
\end{tabular}




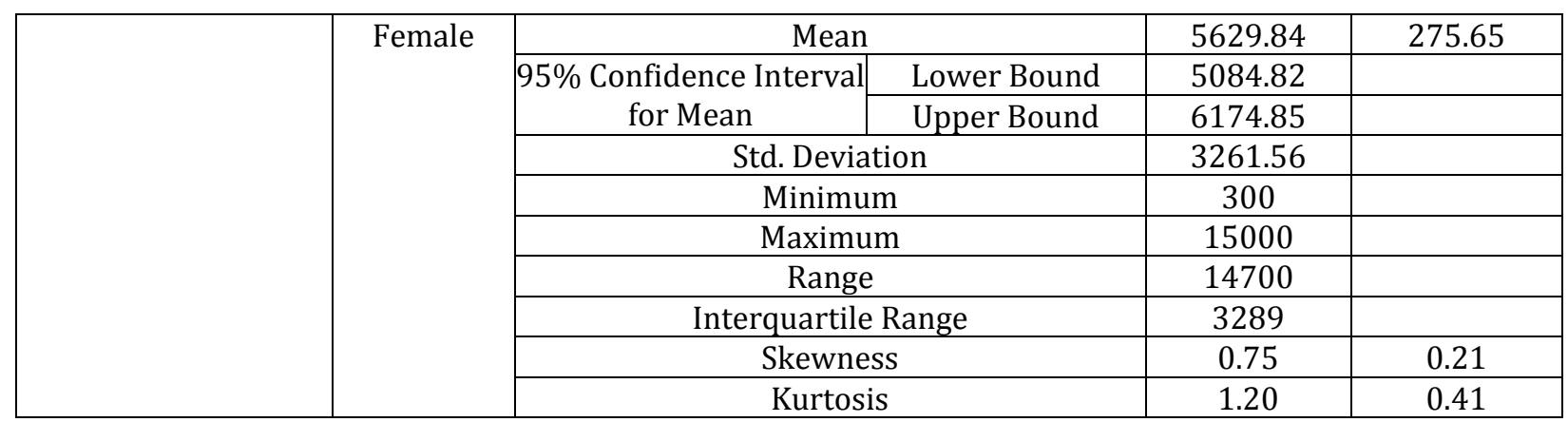

Sources: Computed by author

The above table shows the independent samples Normality test for examining whether the problems faced in social class groups are different for the male and female respondents. The test results give a sig value of health care expenditure and income-earning of the households are 0.00 for male and 0.00 for female related problems faced by the health problem two categories of respondents i.e. the male and female.

This allows the researcher to accept the null hypothesis $\mathrm{H}_{01}$. Therefore, it can be concluded that there exists no significant difference between the problems faced by the male and female respondents in rubber cultivation. Again, it is also inferred that there exists no significant difference in the problems faced by male and female respondents in social class groups.

\section{Null Hypothesis}

$\mathrm{H}_{01}$ : There is no significant difference exist in the problems faced by male and female respondents in
Primary Occupation and Secondary Occupation. (Accept the Null Hypothesis)

\section{Impact of occupational type on the level of living of the respondents}

This part of the analysis deals with the group between the standard of living or the level of living of the respondents and the type of occupation they are involved in. It is evident from the demographic analysis that the social group respondents are associated with primary and secondary occupation and some of them associated with them both. As there are three groups Ftest or ANOVA is the only method for finding out the impact of the types of occupation on the level of their living.

Before going for the hypothesis testing, the assumption of the ANOVA test has to be ensured for the test variables. The test variable is continuous metric data from the level of living and so the estimation method has been given in the following paragraph.

Table-21: Summary Statistics of Households

\begin{tabular}{|l|c|c|c|c|c|}
\hline & $\begin{array}{c}\text { Average Age of } \\
\text { Responded of } \\
\text { family Member }\end{array}$ & $\begin{array}{c}\text { Average Age of } \\
\text { Sex ratio of } \\
\text { family Member }\end{array}$ & $\begin{array}{c}\text { Average Cast } \\
\text { ratio family } \\
\text { Member }\end{array}$ & $\begin{array}{c}\text { Average } \\
\text { types of a } \\
\text { family } \\
\text { member }\end{array}$ & $\begin{array}{c}\text { Monthly } \\
\text { income of } \\
\text { Family } \\
\text { Member }\end{array}$ \\
\hline Mean & 35.59 & 1.4 & 2 & 1.54 & 4807.91 \\
\hline Standard Error & 0.56 & 0.03 & 0.04 & 0.03 & 101.09 \\
\hline Median & 34 & 1 & 2 & 2 & 5100 \\
\hline Mode & 32 & 1 & 2 & 2 & 3000 \\
\hline Standard Deviation & 10.39 & 0.49 & 0.82 & 0.5 & 1885.86 \\
\hline Sample Variance & 108.06 & 0.24 & 0.67 & 0.25 & 3556467 \\
\hline Kurtosis & -0.5 & -1.85 & -1.5 & -1.99 & 0.02 \\
\hline Skewness & 0.51 & 0.4 & 0 & -0.16 & 0.69 \\
\hline Range & 42 & 1 & 2 & 1 & 7895 \\
\hline Minimum & 18 & 1 & 1 & 1 & 2105 \\
\hline Maximum & 60 & 2 & 3 & 2 & 10000 \\
\hline Sum & 12386 & 488 & 696 & 536 & 1673151 \\
\hline Count & 348 & 348 & 348 & 348 & 348 \\
\hline
\end{tabular}

Sources: Computed by author 
The final regression model can be written as follows

\section{Estimation of Level of Living}

The level of living is one of the most important and key dependent variables of this research. It is a function of the social, economic and political factors of the respondents. It is estimated by using variables like; the type of house owned by the respondents, the actual ownership of a house, the size of the house where a person is living, whether the respondent is having electricity supply to his house, supply of water and source of drinking water at home, type of fuel used for cooking, number of assets owned, whether their children go to school or get primary education and higher education, whether the respondent has a voter ID card and bank account. Besides all these variables another important variable added is the savings to income ratio. This ratio is an important element that varies with the status; for example, a person having a higher saving to income ratio certainly has more money for spending on luxury items which is an indication of an increased standard of living. It also increases the bank balance and cash in hand. Besides, this variable also helps in managing the credibility and indebtedness of the respondent. An average of these variables is taken to arrive at the estimation of the level of living of the respondent.

Level of living: Average (Ratio of saving to earning, house ownership, house type, house size, electricity supply, source of drinking water, fuel for cooking, children's education, bank account, voter ID card and several assets owned.

Savings: Total earning income in the household per month - Total food and healthcare expenditure of the household per month.

The Ratio of Saving to Earning: Total saving of the household per month/Total earning or income of the household per month.

\section{Test of Normality:}

Normality is the prime requirement for parametric tests like t-test or ANOVA. Therefore, it is necessary to test whether the metric variable i.e. the dependent variable is normally distributed. For this, the histogram graph and the normal Q-Q plot are given below which indicates that the data is normally distributed and is fit for the ANOVA test.

Figure-15: Normality Test for Level of Living Estimate

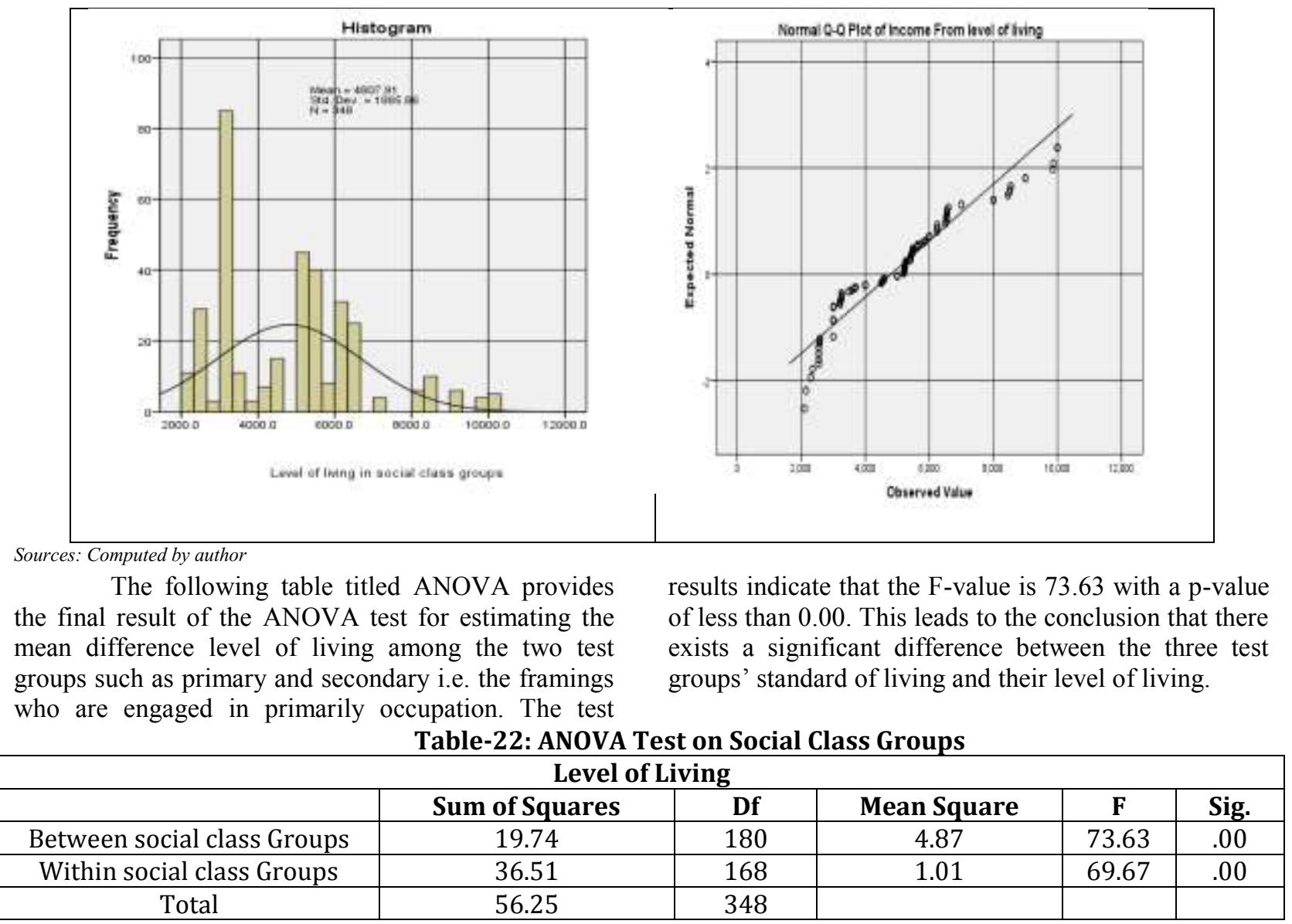

Sources: Computed by author 
The following table gives the ANOVA analysis result which is important to understand the difference between each group with other groups. It can be observed that all three test groups show a significant difference in the level of the living estimate. It can be concluded from the ANOVA analysis that the respondents who are involved in a different type of (primary along with secondary) framing are having a higher level of living compared to those who are engaged only in labourer. As such, the respondents who are not engaged in framing cultivation at all are showing a very poor level of living compared to the other two test groups.

Again, those respondents working in their field as well as in others field as a labourer show a higher level of living compared to the other two groups.

\section{Null Hypothesis:}

$\mathbf{H}_{\mathbf{0 2}}$ : There is no significant impact on the type of social class respondents grouped according to the type of work they are doing on their level of living. (Rejected)

\section{Impact of health care expenditure burden on the socio-economic condition of the Khallikote Block in Ganjam}

Rationale: Even though the ANOVA test for the socio-economic condition between the two types of income and health status, it also claims that those respondents who are involved in both the type of income are having a higher standard of living among all the groups. But the problem with the ANOVA test is it does not consider the influence of the other variables while estimating the health care burden or impact on the social-economic condition. Therefore, a regression model is highly essential to examine whether the level of living is related to the type of income or it is just a matter of chance.

Table-23a: Regression Model Summary

\begin{tabular}{|c|c|c|c|c|c|}
\hline Model & $\mathbf{R}$ & R Square & Adjusted R Square & $\begin{array}{c}\text { Std. Error of the } \\
\text { Estimate }\end{array}$ & Durbin-Watson \\
\hline 1 & $0.63^{\text {a }}$ & 0.39 & 0.39 & 0.23 & 1.91 \\
\hline $\begin{array}{l}\text { a. Predictors: (Constant), Health Care Expenditure, Life Insurance, Utilisation by Children Below } 5 \text { Years } \\
\text { Age, Total Family Saving, Toilet Position, Utilisation by Pregnant Women }\end{array}$ \\
\hline \multicolumn{2}{l}{ b. Dependent Variable: Level of income } \\
\hline
\end{tabular}

Sources: Computed by author

Table-23b: ANOVA for Estimating Goodness of Fit of the Regression Model

\begin{tabular}{|c|c|c|c|c|c|}
\hline & Sum of Squares & df & Mean Square & F & Sig. \\
\hline Regression & 17.91 & 6 & 2.99 & 62.37 & $.000^{\mathrm{b}}$ \\
\hline Residual & 27.36 & 593 & 0.08 & & \\
\hline Total & 45.24 & 599 & & & \\
\hline a. Dependent Variable: Level of income \\
\hline $\begin{array}{l}\text { b. Predictors: (Constant), Health Care Expenditure, Life Insurance, Utilisation by Children Below 5 Years } \\
\text { Age, Total Family Saving, Toilet Position, Utilisation by Pregnant Women }\end{array}$ \\
\hline
\end{tabular}

The presence of other variables such as; Nonfarming Activity like whether the respondent is involved only in a secondary occupation or other activities like daily labour or something like that, Ratio of family size to the total employed or earning whether the respondent has a farming land or not, Indebtedness is also a control variable that has a significant impact on the living standard. It includes whether the individual currently possesses any loan and if he takes a loan frequently or rarely. Finally, holding of other work also influence in generating an extra income. These five variables are taken as control variables to examine the influence of the independent variable type of health expenditure on the dependent variable level of living.

\section{The Model:}

The regression result has been presented in the following tables. The first table presents the regression model summary. It gives information regarding the variables in the model and the value of the regression coefficient $\mathrm{R}$ and the coefficient of determination $\mathrm{R}$ square. The value of $\mathrm{R}$ as given by the model is 0.622 and R-square is 0.387 . This means that in the regression model the dependent variable is explained by the independent variables is $38.7 \%$. The DurbinWatson value is given by 1.893 which is greater than the value of R-square which specifies that the regression model is not a spurious one. The ANOVA table with a significant F-value indicates the goodness of fit for the regression model. The estimated F-value is given by 62.365 with a p-value of 0.000 which is significant at a 0.01 level of significance. So, it can be inferred from the above discussion that the regression model is valid and fit. members in the family (EMF), Land Holding i.e. 
Table-23c: Regression Coefficients

\begin{tabular}{|c|c|c|c|c|c|c|c|}
\hline $\begin{array}{c}\text { Dependent Variable: } \\
\text { Level of Living }\end{array}$ & \multicolumn{2}{|c|}{$\begin{array}{c}\text { Unstandardized } \\
\text { Coefficients }\end{array}$} & $\begin{array}{c}\text { Standardized } \\
\text { Coefficients }\end{array}$ & $\mathbf{t}$ & Sig. & \multicolumn{2}{|c|}{$\begin{array}{c}\text { Collinearity } \\
\text { Statistics }\end{array}$} \\
\cline { 2 - 8 } & $\mathrm{B}$ & Std. Error & Beta & & & Tolerance & VIF \\
\hline (Constant) & 1.09 & 0.03 & & 33.45 & 0.00 & & \\
\hline $\begin{array}{c}\text { Health Care } \\
\text { Expenditure }\end{array}$ & 0.09 & 0.02 & 0.27 & 7.88 & 0.00 & 0.84 & 1.19 \\
\hline $\begin{array}{c}\text { Utilisation by Children } \\
\text { Below 5 Years Age }\end{array}$ & 0.16 & 0.09 & 0.20 & 6.07 & 0.00 & 0.89 & 1.16 \\
\hline Total Family Saving & -0.06 & 0.06 & -0.06 & -1.17 & 0.03 & 0.99 & 1.04 \\
\hline Toilet Position & 0.05 & 0.01 & 0.19 & 5.69 & 0.00 & 0.88 & 1.19 \\
\hline $\begin{array}{c}\text { Utilisation by Pregnant } \\
\text { Women }\end{array}$ & -0.08 & 0.04 & -0.08 & -2.06 & 0.04 & 0.96 & 1.08 \\
\hline Life insurance & 0.16 & 0.09 & 0.25 & 7.09 & 0.00 & 0.89 & 1.15 \\
\hline Sources: Computed by author
\end{tabular}

The regression result presented in table-23.c shows the standardized and unstandardized beta coefficients of the regression equation. It also provides information regarding the $t$-statistic and the corresponding $p$-value. It can be inferred from the above table that Health Care Expenditure, Life Insurance, Utilisation by Children Below 5 Years Age, Total Family Saving, Toilet Position, Utilisation by Pregnant Women variables significantly explain the dependent variable levels of living. Whereas, the ratio of family size to earning members in the family does not significantly explain the level of living but it negatively influences the dependent variable. It means, the increase in the ratio has a negative impact on the level of living but the effect is not significant at a $5 \%$ error level. On the other hand, the variable life insurance or toilet position is also negatively related to the level of living at a $5 \%$ significance level. This leads to the conclusion that an increase in the debt position of a household or a person affects the level of living but it is only Significant at a $5 \%$ error level but not at a $10 \%$ error level as the corresponding $\mathrm{p}$-value is 0.04 , which is very close to 0.05 .

Further, it is observed that the health care expenditure is in agreement with the ANOVA test results discussed earlier in this chapter for finding the impact of family income type on the level of living of the Khallikote block in Ganjam districts. The regression results also confirm that there is a significant relationship between health expenditure and income.

Again, it is concluded that the involvement of the respondents in money-earning activities other than health expenditure is also significantly increasing the standard of living of the households. Similarly, the total saving and life insurance holding are also significantly predicting the standard of living. After taking five control variables in the regression model the type of health care expenditure shows a significant positive relationship with the level of income household. This leads to the rejection of the null hypothesis as there is no significant impact.

\section{The final regression model can be written as follows}

Level of family income $=1.09+0.09$ (Health care Expenditure) +0.16 (Utilisation by Children below 5 Years Age) -0.06 (Total Family Saving) +0.05 (total toilet) -0.06 (saving) +0.16 (life insurance)

The chi-square test is appropriate to analyse the preference level of the respondents.

Table-23d: Chi-Square Tests

\begin{tabular}{|c|c|c|c|}
\hline & Value & df & Asymptotic Sig. (2-sided) \\
\hline Pearson Chi-Square & $10.56^{\mathrm{a}}$ & 2 & .05 \\
\hline Likelihood Ratio & 10.69 & 2 & .05 \\
\hline Linear-by-Linear Association & 1.38 & 1 & .03 \\
\hline $\mathrm{N}$ of Valid Cases & 348 & & \\
\hline
\end{tabular}

The chi-square test at 2 degrees of freedom gives rise to a significant $\mathrm{p}$-value which is 0.05 . This result leads to the conclusion that there is a significant difference between the preference of male and female 
Khallikote block are four villages towards a different type of family income. Thus, it rejects the null hypothesis given below.

Table-24: Regression results Dependent variable = Ln (health expenditure+1)

\begin{tabular}{|c|c|c|c|c|}
\hline & \multicolumn{2}{|c|}{ Model 1} & \multicolumn{2}{|c|}{ Model 2} \\
\hline & Coefficient & $P>t$ & Coefficient & $\mathrm{P}>\mathrm{t}$ \\
\hline Constant & 5.27 & 0.00 & 4.53 & 0.00 \\
\hline ST & -3.42 & 0.00 & -2.96 & 0.00 \\
\hline SC & -0.96 & 0.00 & -0.62 & 0.00 \\
\hline $\mathrm{OBC}$ & -0.12 & 0.42 & -0.17 & 0.09 \\
\hline \multicolumn{5}{|c|}{ Household's landholdings } \\
\hline No land & -0.40 & 0.03 & -0.41 & 0.02 \\
\hline \multicolumn{5}{|l|}{ Need } \\
\hline High & 0.72 & 0.00 & 0.39 & 0.00 \\
\hline Very high & 1.71 & 0.00 & 0.47 & 0.01 \\
\hline \multicolumn{5}{|c|}{ Sex of household head } \\
\hline Male & 0.04 & 0.32 & 0.79 & 0.05 \\
\hline Female & 0.06 & 0.68 & 0.21 & 0.11 \\
\hline \multicolumn{5}{|c|}{ The utilisation of health care } \\
\hline Visits: Government & & & 0.04 & 0.12 \\
\hline Visits: Private & - & - & 0.07 & 0.01 \\
\hline Hospitalization: Government & - & - & 0.51 & 0.06 \\
\hline Hospitalisation: Private & - & - & 0.53 & 0.01 \\
\hline R-squared & \multicolumn{2}{|c|}{0.47} & \multicolumn{2}{|c|}{0.62} \\
\hline Adjusted R-squared & \multicolumn{2}{|c|}{0.46} & \multicolumn{2}{|c|}{0.61} \\
\hline
\end{tabular}

Note: Model 1: $\ln$ (health expenditure) = f (caste, landholdings, health care need), Model 2: ln (health expenditure $+\operatorname{Re} 1)=\mathrm{f}$ (caste, landholdings, health care need, the number of government and private visits and hospitalisations)

Source: primary household's survey

The regression result has been presented in the following tables. The first table presents the regression model summary. It gives information regarding the variables in the model and the value of the regression coefficient $\mathrm{R}$ and the coefficient of determination $\mathrm{R}$ square. The value of R-square as given by the model is 0.47 and the adjusted R-square is 0.46 . This means that in the regression model the dependent variable is explained by the independent variables is $5.27 \%$. The model one and two values are given by 0.47 and 0.62 which is greater than the value of R-square which specifies that the regression model is not a spurious one. The model 1 and model 2 table with a significant $p>t$ value indicates the goodness of fit for the regression model. The estimated p-value is given by 0.12 and 0.06 visit in Govt. hospital with a p-value of 0.01 which is significant level at 0.01 in Pvt. So, it can be inferred from the above discussion that the regression model is valid and fit.

Again, it is concluded that the involvement of the respondents in money-earning activities other than the secondary occupation is also significantly increasing the standard of living of the households. Similarly, landholding and life insurance holding are also significantly predicting the standard of living. After taking three control variables in the regression model the type of OBC household's utilisation of health care used in high spending shows a significant positive relationship with the level of living.

\section{Hypotheses Testing Overview} given below.
The summary of the hypothesis tested are 
Table-25: Summary of the Null Hypotheses

\begin{tabular}{|c|c|c|}
\hline $\begin{array}{l}\text { Null Hypothesis } \\
\end{array}$ & Statistical Tool Used & Test Results \\
\hline $\begin{array}{l}\mathbf{H}_{\mathbf{0 1}} \text { : There is no significant difference exist in the problems } \\
\text { faced by male and female respondents in Primary } \\
\text { Occupation and Secondary Occupation. }\end{array}$ & $\begin{array}{c}\text { t-test }=-1.43 \\
\text { p-Value }=0.15(>0.05)\end{array}$ & (Accepted) \\
\hline $\begin{array}{l}\mathbf{H}_{\mathbf{0 2}} \text { : There is no significant impact on the type of social class } \\
\text { respondents grouped according to the type of work they are } \\
\text { doing on their level of living. }\end{array}$ & $\begin{array}{c}\text { t-test }=0.85 \\
\text { p-Value }=0.40(>0.05)\end{array}$ & (Rejected) \\
\hline
\end{tabular}

\section{Limitation of the Study}

The study has the following limitations:

1. The study has depicted the current situation of the Khallikote Block in Odisha; the result may not be relevant to other class of people.

2. The study is limited to a cross-section sample of 348 households of the selected sample villages in Langaleswar and Khojapalli Panchayat.

3. It has been assumed that the respondents are true and honest while filling the questionnaire and there is no bias.

4. Level of satisfaction is a relative term and in this regard, the views of the beneficiaries cannot be accepted whole-heartedly.

5. Due to time and resource limitations, a fulllength survey is not possible with a wider representation of data.

Despite these limitations, an attempt has been made to make the study more scientific and reliable by testing the reliability of the primary data.

\section{CONCLUSION}

The various indicators emerging from the sample data show that the Khallikote primary centre area is relatively better off than Langaleswar, which in turn is better off compared to Kumarsing. The Kumarsing appears to be the most backward of the three areas in terms of basic infrastructure and human development indicated by lower levels of per capita income. The three caste groups' widely reported health expenditures to correlate to their position within the caste hierarchy, with FC disbursal being the highest and Khallikote Block disbursal being the lowest. Variations in per capita health expenditure by various caste groups are a transparent measure of their unequal access to quality health care in a significant context of practically no insurance coverage, insufficient state provision of health care, and the dependent on nonpublic suppliers. When dominant for health care needs and efficient confounders, statistical methods supported this caste-related difference. Households with high healthcare needs and chronic healthcare needs were observed to suffer almost as a result of this disparity among the ST, SC, and OBC caste groups. This necessitates a current investigation into the broadly accepted idea that Odisha has much less social disparity in health-care access. The vessel caste gradients for high-need and high-need families, as well as chronic care events, are direct indicators of the lower castes' extreme deprivation in accessing care, particularly in high and chronic health care.

According to our findings, a household with high healthcare expenditures is more likely to attain significant health expenditures. Despite their low per capita health expenditure, the Khallikote Block is the most vulnerable among the lower castes even to the most minimum standards of health care. As a result, to completely protecting regular tribe households, especially the Khallikote Block tribes, from impoverishing health expenditures, there's a powerful need to be compelled to defend all households with a high potential need for health care, particularly households with members who are senior and/or infected by serious disease. Validation of our concept of health care would have seen that children from families and very high-need have the highest sickness burden, as reflected by their use of outpatients visits and medical aid for acute and chronic episodes. Medical help expenditures tend to have the most impoverishing effects on households, as shown by the sources of finance, particularly on Khallikote Block, ST, SC, and OBC households. Special focusing on funding medical support, since this expenditure brings families in a more challenging position in terms of mobilising financial resources than outpatients visits. Five limitations should be listed about the scope of our research. 
Figure-16: Filed Study Area in Khallikote Block in Ganjam

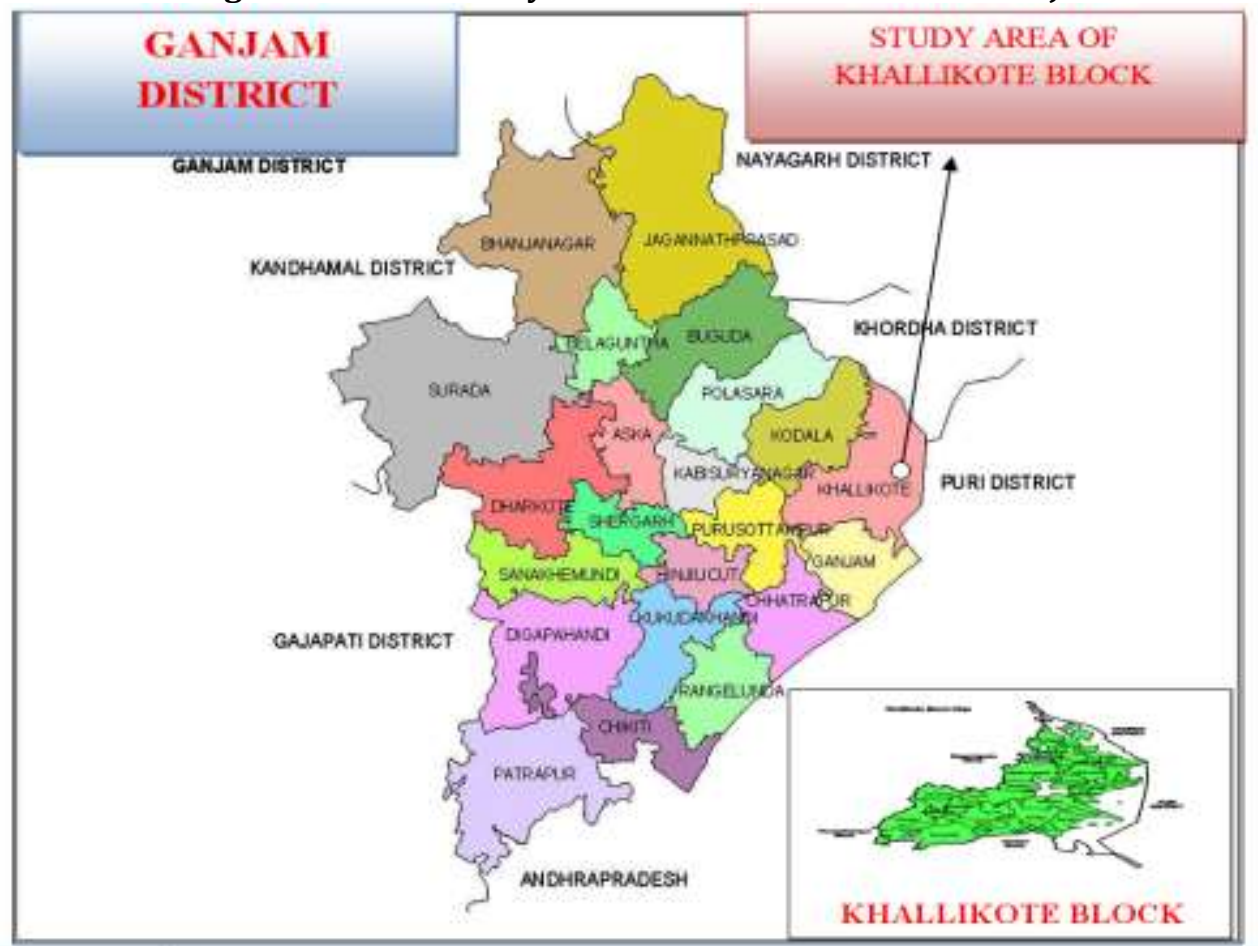

\section{REFERENCES}

1. Marmot, M. \& Wilkinson, G. R. (1999). Social Determinants of Health. Oxford: Oxford University Press; Sen A: Development as Freedom. New Delhi: Oxford University Press.

2. Nayar, K. R. (2007). Social exclusion, caste \& health: a review based on the social determinants framework. Indian J Med Res 2007, 126(4):355-363.

3. Sen, G., Ayer, A. \& George, A. (2002). Class, gender and health equity: lessons from liberalizing India. In Engendering International Health: The Challenge of Equity, Cambridge, MA: MIT Press, 1(1): 281-311.

4. Ensor, T., \& Cooper, S. (2004). Overcoming barriers to health service access: influencing the demand side. Health Policy Plan, 19(2):69-79.

5. Berman, P., Ahuja, R., \& Bhandari, L. (2010). The impoverishing effect of healthcare payments in India: new methodology and findings. $E P W, 45(16): 65-71$.

6. Deshpande, A. (2000). Does caste still define disparity? A look at inequality in Kerala, India. Am Econ Rev, 90(2):322-325.

7. Jain, $S$. K. (2004). Identification of the poor: flaws in government surveys. EPW, 39(46\&47):4981-4984.

8. Mukherjee, N. (2005). Political Corruption in India's Below the Poverty Line (BPL) Exercise: Grassroots' Perspectives on BPL in Perpetuating Poverty. Social Exclusion New Delhi: Development Track in Research, Training and Consultancy.

9. Alkire, S. \& Seth, S. (2008). Multidimensional Poverty and BPL Measures in India: A Comparison of Methods. Oxford Poverty and Human Development Initiative Working Paper 15 Oxford: Oxford University. 